\title{
CONSIDERACIONES SOBRE LA OBRA DE MIGUEL HERRERO DE MIÑÓN EN TORNO A LOS DERECHOS HISTÓRICOS
}

\author{
CARLOS COELLO MARTÍN \\ Profesor de Derecho Administrativo \\ Universidad de La Rioja
}

\begin{abstract}
Juan Maria JAUREGI'ri oroimenez, Stalinen semeak erailia. Jose Ramon REKALDE Jaunari "biru egun era biru gau igaro zituelakotz beriotz baleinaren sabelean" egon ondoren, bere abutzatik bela egiteagatik.

(Jonas, 2.1)

Pra Arturo Leyte, o millor navegante do mondo
\end{abstract}

"Bien, ¿has resuelto ya el enigma de los irlandeses?

-dijo Finn

-Son como un crucigrama sin números- dije, marcando con rojo una escena de mi guión, que tenía esparcido sobre la barra.

Sí que somos eso- dijo Finn orgullosamente.

Era la hora antes de abrir y Finn me había dejado entrar por la puerta lateral para que pudiera despellejar tranquilamente, si no resolver, la Ballena y sus competencias.

-No hay ni uno de nosotros que sepa quién es, ni queremos saberlo - añadió Finn frotando la barra como si sus palabras hubieren estado alli temporalmente y ahora tuviera que borrarlas-. Somos un misterio dentro de una

UNED. Teoria y Realidad Constitucional, núm. 5, 1. ${ }^{\mathrm{er}}$ semestre 2000, pp. 399-436 
caja dentro de un laberinto sin puerta ni llave. Somos una sopa con mucho aroma pero nada de sustancia". ${ }^{1}$

"Guipúzcoa, libre e independiente o autónoma, como ahora decimos, se incorporó voluntariamente a la corona de Castilla en el año 1200, reinando Alfonso VIII. Nuestros antepasados, tan prudentes como valerosos, sacrificaron de grado, parte de su libertad, la menor posible, por asegurar la suma mayor que les fue dada, bajo la égida del trono de Castilla: esta suma de libertad salvada es lo que conocemos con la denominación de fueros, buenos, usos y costumbres. La Corona de Castilla al aceptar la cesión que de parte de su libertad hizo Guipúzcoa a favor de ella se comprometió a respetar la parte reservada por esta Provincia; no son pues nuestros Fueros privilegios otorgado por la Nación, y sí derechos reservados al incorporarnos a ella, y la condición sine qua non de nuestra unión. Si Castilla no cumple su compromiso, indisputable es nuestro derecho a declarar rota la unión y a recuperar nuestra independencia, como lo hicieron nuestros abuelos respecto al Reino de Navarra, del que formó parte Guipúzcoa antes que de Castilla". ${ }^{2}$

\section{DEL ESTADO DE LA MAR CONSTITUCIONAL Y LAS GALERNAS EN EL GOLFO DE VIZCAYA. LOS APAREJOS DE PESCA DE LA MISTERIOSA Y SAGRADA JUSTICIA CONSTITUCIONAL. DEL ARTE DE MAREAR DEL CONSTITUCIONALISMO ESPAÑOL}

La cuestión vasca es el centro de atención de multitud de trabajos de carácter histórico, sociológico, político, y también, de carácter jurídico. ${ }^{3}$ Desde un punto de vista jurídico él derecho constitucional pretende resolver un dato cierto, el "malestar nacional", 4 así como la discusión sobre la "legitimación" del Estado Español en las provincias que fueron llamadas "exentas", y la resolución del problema político-constitucional de como aparejar Vasconia en y con España. ${ }^{5}$ Este conflicto

1. Tomado de Ray Bradbury, Sombras verdes, ballena blanca. Ediciones Minotauro, Barcelona, 1995. Pág. 131.

2. El texto pertenece al artículo de Miguel De Dorronsoro, titulado, Lo que fueron los reyes de España y lo que ha sido el liberalismo para con los fueros de Guipúzcoa. Lo recoge Vicente GARMENDIA, en la recopilación de textos, "Jaungoicoa eta foruac. El carlismo vasconavarro frente a la democracia española (1868-1872)", dentro de la expléndida colección de Textos Clásicos del Pensamiento Político y Social en el País Vasco, editado por la UPV-EHU.

3. Puede consultarse la extensa biliografía, bien que cerrada en el año 1994, que acompaña Virgina TAMAYO SALABERría, La autonomía vasca contemporánea. Foralidad y estatuismo 1975-1979, IVAP, 1994.

4. Retomo las ideas apuntadas por Pietro BARCELLONA, "Los sujetos y las normas. El concepto de estado social", en Enrique Olivas, Problemas de legitimación en el Estado Social, Editorial Trotta, Madrid, 1991 , sobre el "malestar urbano".

5. A las causas del déficit de legitimidad del Estado social por Enrique Olivas, Problemas de legitimación en el Estado Social, ob. cit. pp. 11 y ss. hay que sumar la cuestión recurrente en el Estado de derecho, de la "cuestión nacional". Dado que como apunta Toscano Méndez, aun cuando no extrae todas las consecuencias derivadas de su afirmación, el Estado contemporáneo, debe promover la identificación y lealtad de sus ciudadanos, de lo que resulta una transformación culatitativa de sus necesidades de legitimación. (Vide "iDemocracia de los ciudadanos o democracia de las nacionalides?" Rubio Carracedo, Rosales, Toscano, Ciudadanía. Nacionalismo y derechos bumanos. Editorial Trotta, 
político-constitucional, aun cuando poderososas razones de estado pretenden reducirlo, a un grave pero mero problema de orden público, existe.

Hijos del terror se encuentran ciertamente el crimen y la banalización del mal, característicos de la sociedad moderna, como recordara Hanna Harendt, y como efectos perversos concatenados, la reducción de las expresiones, ideológicas o jurídicas, plurales, dañando directamente uno de los principios fundamentales del Texto Constitucional, según una reiterada doctrina: el pluralismo político que consagra el artículo $10^{\circ}$ de la Constitución Española de $1978 .^{\circ}$

Se ha producido, una tenebrosa coincidentia opositorum: la voluntad expresada, como convención constitucional, de hacer formalmente del problema vasco una mera cuestión de inseguridad ciudadana, orden público, se ve arropada por la actuación criminal de ETA, que sustituye, materialmente el problema político, por la aplicación de la "normativa de la emergencia" constitucional, penal y administrativa, en un claro hermanamiento antigarantista (Muñagorri Laguia). ${ }^{7}$

Las acciones criminales de ETA, ocultan la cuestión vasca, y la sustituyen en cuestión de orden público. Enquistada carga pública que no supone ningún riesgo a la "quietud" del Leviathan, sino que cada crimen de ETA, produce el efecto contrario y deseado, de manera hobbesiana; creando una relegitimación del Estado como titular del "monopolio de la violencia legítima", en terrenos otrora yermos. ${ }^{8}$

La jibarización de la cuestión vasca, su redución a mero orden público, a una cuestión onírica, o a otras explicaciones de carácter psicológico colectivo, deforman, conscientemente, en nuestro criterio, el enfoque democrático y constitucional. Revelan, además, reflejos de "tolerancias represivas", y manifiestan que la cultura constitucional y democrática española, sigue siendo, como la capa vegetal de las montañas gallegas, escasa.

Madrid, 2000, pp. 104 y ss. O parafraseando su texto, ¿la unidad constitucional de España há de entenderse que encubre la subordinación de la ciudadanía a la nacionalidad española, sin consideraciones de justicia y equidad, para esa comunidad imaginada vasquista que ni se identifica ni puede ser leal con la comunidad imaginada española?

6. Este fenómeno no solo es español o vasco. Escribe Conor Cruise O'Brien, Genio y pasión y otros ensayos, FCE, Mexico, 1994, pp. 229 y ss. al referirse al caso irlandés, cómo "el terrorismo perturba, no solo emocional y moralmente, sino también intelectualmente".

7. Esta coincidentia opositorum, y la relegitimación del Estado en situación necróticas de violencia criminal, y como la inseguridad ciudadana ha venido a sustitur el caduco concepto de orden público, se recogen en diversos trabajos publicados, bajo edición de I. MuÑagorri LaGuia, La protección de la seguridad ciudadana. Oñati Proceedings, 1995. De entre los diversos trabajos de interés son sugerentes las lecturas de CALvo GARĆ́A. Politicas de seguridad y transformaciones del Derecho, pp. 95 y ss. Frances BARATA, Las nuevas fábricas del miedo. Los mass media y la inseguridad ciudadana, pp. 83 y ss., Begoña LANDA ARAMBARRI, La Ley Orgánica.... una estrategia preventiva de control politico, págs 247 y ss., Ignacio MuÑagorRI LAGUIA, Del estado protector a la autoprotección del Estado ¿Hacia una nueva codificación?, pp. 287 y ss. Y Laura ZúÑiGa RoDRígueZ, La Ley de seguridad ciudadana: un síntoma de la crisis del poder ejecutivo. Especial consideración del sistema penal, pp. 441 y ss. Esa perversa influencia del terrorismo en la normativa de emergencia,, y que produce una auténtica mutación constitucional, había sido denunciada por Diego López GARrido, Terrorismo, política y derecho, Alianza Editorial, Madrid, 1987, pp. 147 y ss.

8. Esta consideración se aprecia en algunos trabajos de la cosmopolita sociedad americana, Vide, ad exempla, Mark KunLANSKY, The basque bistory of the world, Walker \& Company, New York, 1999. pp. 285 y ss. 
Reducida a orden público, la política nace como razón de estado, es corregimiento gubernativo, que si mira al poder, es por buscar el orden, por recuperarlo. 9 Como advirtiera Saavedra Fajardo, la razón de Estado resultaba como una sombra que se alargara con el ocaso, las sombras de la razón de Estado suelen ser mayores que el cuerpo. ${ }^{10} \mathrm{El}$ "robot Leviathan, la institución político-constitucional, salva del monstruo Behemoth, representado icónicamente como una nueva ballena vizcaína, extingida del Golfo de Vizcaya, por los arpones y traineras que glosan las coplas tradicionales vascas. La taxidermia del monstruo Behemoth se nombra: ETA es el problema vasco y es nacionalismo vasco. Es corregimiento gubernativo repetirlo ad nauseam. Es poder simbólico del Estado (BOURDIEU). ${ }^{11}$

Empero, sin necesidad de invocar "ad minutias" la historia española, la teoría y la praxis de violencia de la falange vasca, revelan su ideología y praxis estalinista, más cercana y heredera de una españolísima tradición, (de derechas y de izquierdas) ${ }^{12}$ del "alanceamiento" de presos, de sacas o de paseos, que del pensamiento y de la práctica histórica del nacionalismo vasco. ${ }^{13}$

9. Bartolomé Clavero, Razón de Estado, razón de individuo, razón de bistoria, Centro de Estudios Constitucionales, Madrid, 1991, p. 31 y passim.

10. Citado por Clavero, ob. cit., p. 34, haciendo suyos los apuntes de Francisco Murillo Ferrol, de su Saavedra Fajardo y la Política del Barroco, Madrid, 1957. Veáse PeÑa Echevería, Estudio preliminar, a la recopilación La razón de Estado en España. Siglos XVI-XVII (Antología de textos). Editorial Tecnos, Madrid, 1998.

11. Pueden encontrarse algunas sugerencias en Poder, Derecho y clases sociales, Edición Desclée, Bilbao, 2000.

12. Puede consultarse el reciente libro de Manuel MarTORell, Jesús Monzón, el lider comunista olvidado por la Historia, Editorial Pamiela, Pamplona-Iruña, 2000, pp. 46 y ss. y passim. donde se refleja, por ejemplo, el respeto del dirigente comunista por la actuación de los dirigentes nacionalistas en las épocas de "paseos" o "sacas". Desde una cultura antiestalinista, los testimonios de Victor AlBA, Memorias de un Cabreado, Editorial Laertes, y Wilebaldo Solano, El Poum en la Historia. Andreu Nin y la revolución española, Los Libros de la Catarata, Madrid, 1999, pp. 127 y ss. refleja los esfuerzos del Ministro de Justicia, el navarro Manuel De IRUjo, nacionalista vasco del PNV, no solo en evitar el asesinato de Andreu NIN y de otros dirigentes poumistas, sino sus esfuerzos por esclarecer el asesinato estalinista, y de introducir la observancia y el respeto a la ley, y su oposición a tales crimenes ni siquiera en el teatro de operaciones de la guerra", según expresión del Constitucionalista Portugués, José Joaquím Gomes CANotillo. Puede leerse sobre NIN, la versión recogida por Peter WeIss, La estética de la resistencia. I. España, antesala de la tragedia, Ediciones Versal, Barcelona, 1987, pp. 257 y ss.

13. Como voz que clama en el desierto, José Antonio ReKondo, Bietan jarrai. Guerra y Paz en las Calles de Euskadi, Euskadi, 1998 lo ha recalcado. Une a su condición de escritor de este trabajo desterrado del pensamiento políticamente correcto, la de haber sido Alcalde Presidente del Ayuntamiento de Hernani, en representación de Eusko-Alkartasuna., lo ha expuesto, certeramente en su página 200: "Es muy cierto que el nacionalismo vasco se encuentra en el punto de mira de una ofensiva descomunal que, orquestada desde lo más fáctico del Estado, se ha recrudecido en esta etapa política (la del Gobierno de AP hoy PP) y pretende abiertamente arrasar con todo lo que les suene a cuestión vasca. Sin embargo, es oportuno recordar que ésta no es una amenaza nueva y que es la debilidad de un nacionalismo a la defensiva la que ha permitido que este españolismo agresivo vaya ganando espacios que la falta de iniciativa política del nacionalismo ha obligado a éste a abandonar. En efecto, la política de domesticación y linchamiento del nacionalismo no es nueva. De hecho los puntos de apoyo de esta estrategia son los mismos que ha tenido siempre, o al menos, desde el inicio de la transición: la larga tradición de la Corte que siempre ha entendido la cuestión vasca como una cuestión de estado. El despiste, incentivado por el anclaje del Estado en la postura anterior, que le lleva a creer que el nacionalismo es el hecho sustantivo en el ideario de ETA y que el leninismo es un mero adhesivo en el mismo. La posición, extendida bajo el manto de una determinada progresía que vindica para sí una vocación universal, de que el nacionalismo vasco, en la medida en que defiende la identidad y el derecho histórico es una ideología 
La razón de estado se ha convertido en el gran truchimán de los lugares oscuros del Estado, fomentando la inmunidad e interiorizando en el imaginario colectivo, todo aquello que ratifique el fürberprinzip, o si se estima más castizo, el caudillismo, constitucional. Principem totam rempublicam et patriam esse, de suerte que el corregimiento gubernativo se manifieste más como el Leviathan bistórico soberano, que una mera delegación de poder, revocable, del sujeto constituyente desde una cultura jurídica liberal y democrática. Y surge, el simulacro della salute publica. ${ }^{14}$

Como un juego de espejos, ${ }^{15}$ a la deslegitimación política de las instituciones y del propio Leviathan entre una significativa parte de la ciudanía vasca, se ha unido la pérdida de legitimación moral en el ejercicio del monopolio exclusivo de la violencia, dada su conversión en el Golem, en el Bebemoth, ${ }^{16}$ fruto de las prácticas de guerra sucia, toleradas, cuando no promovidas, desde los aparatos del Estado, bajo los gobiernos de la dictadura, de la llamada transición, ${ }^{17}$ y de la democracia (UCD y PSOE), en los que se aprecia un cierto "continuum", tal vez bistoricista. ${ }^{18}$

Esta percepción unidimensional de la cuestión vasca no es nueva. Se reproduce con monotonía, en los "fueros del pensamiento", que diría César VALLEjo, del constitucionalismo español, que, salvo excepciones, ha reflexionado y legislado sobre la cuestión vasca no desde el concepto de nación de ciudadanos sino desde un bucle meláncolico historicista de la "unidad de destino" de la patria hispana. Las Constituciones españolas, a salvo la non nata de la Primera República, y la de la Segunda, han escuchado más las "Voces de los antepasados", han sido más fieles a una imaginada nación histórica, construida a golpe de dictamen histórico. Han estado impregnadas de un nacionalismo español que apenas ha bebido en el

reaccionaria y excluyente». Ha quedado en el olvido un pequeño opúsculo escrito por Ricardo GARCíA DAMBORENEA, titulado Manual del Buen terrorista, Cambio 16, Madrid, 1987, que corrobora lo expuesto. Cierto es, se olvidó escribir un manual simétrico desde las fauces del Leviathan constitucional español. Veáse el resumen de las aportaciones intensas y extensas de Gurutz JAuREGUI, Entre la tragedia y la esperanza. Vasconia ante el nuevo milenio. Ariel, Barcelona, 1996. Recogen los periódicos del 28 de septiembre de 2000, unas declaraciones del Sr. Aznar en el diario Le Figaro-de honda tradición liberal- en las que afirma: "los terroristas de ETA ya no combaten el franquismo sino la democracia. Su objetivo es instaurar un Estado totalitario marxista-leninista en el País Vasco español y también en el País Vasco francés". Parece ser que por fin el antigüo falangista independiente, y experto por tanto en totalitarismos desde "el interior del monstruo", que diría José MARTí, según se definía en la revista falangista SP, ha reconocido la finalidad totalitaria y marxista-leninista de ETA.

14. Bartolomé Clavero, Razón, ob. cit., p. 46.

15. Utilizo la expresión del libro de Francisco LeTAMEndia, Juego de espejos. Conflictos nacionales centro-periferia, Editorial Trotta, Madrid, 1997.

16. Uso con licencia, el texto de Bartolomé Clavero, Razón de Estado, ob. cit., p. 45-46.

17. Algunas notas sobre la legitimidad de origen de la "dinastía histórica" y sobre llamada "reforma política", en Mıguez GonZÁlez, La preparación de la transición a la democracia en España. PUZ, Zaragoza 1990.

18. La continuidad en las prácticas de la guerra sucia, pueden apreciarse con un simple ejercicio: lease el Libro Negro de Montejurra de 1976, el monográfico de la revista Cambio 16 del 27 de noviembre de 1995, titulado "Los padres del GAL", y cualquiera de los libros publicados sobre el terrorismo de Estado, que se ciñen casí exclusivamente, por razones bibliográficas, al período del gobierno del PSOE. Y comparénse los nombres de los "agentes" del Estado. Las reflexiones de Josu CHUECA, 40 urte eta gero bau! Franco ondoko trantsizio politikoa Euskal Herrian, en JAKIN, núm. 113, 1999, pp. 41 y ss. son preguntas que no han obtenido otra respuesta que la "amnesia estructural. Se ha referido, parcialmente, a estas cuestiones Joaquín NAVARro, Buenos dias, Euskadi, Ediciones Foca, Madrid, 2000, passim. 
pensamiento jurídico liberal o democrático. ${ }^{19}$ No es nuestro menester ahondar en la historia constitucional sobre la cuestión vasca y el recurrente domuit vascones. Sin embargo como expresión de ese fuero del pensamiento sirva una reseña espigada en el regeneracionismo español.

Se preguntaba Ramón y Cajal "Qué debemos hacer si, desengañado nuestro optimismo, dos o más regiones estatutarias se declaran plenamente independientes? Y se contestaba: «Si yo pudiera retroceder a mis veinticinco años, henchido de patriotismo exasperado, contestaría sin vacilar: la reconquista manu militari, y cueste lo que cueste. Propondría la máxima de Gracián (contra malicia, milicia). Pero en los tiempos aciagos en que vivimos, dos guerras civiles equivaldrían a la bancarrota irremediable de España y la consiguiente intervención extranjera. Además una guerra suscita automáticamente nuevos conflictos bélicos. Fuerza es convenir en que la fuerza, aplicada a las pugnas intestinas de un país, no resuelven nada. Enconaría las antipatías y cerraría el paso a soluciones de cordial convivencia. En trance de balcanización inminente -según frase de Marsillach- yo, si me asistiera el talento político y fuera diputado a Cortes, propondría pura y simplemente la separación de las regiones rebeldes, separación amistosa y hasta acompañada de algunas compensación fiscales". El admirado médico aragonés, concluía sus reflexiones de un arteroesclerótico reclamando un nuevo cirujano de bierro, que sanara cisoriamente el cuerpo enfermo. ${ }^{20}$

Los fueros del pensamiento, hogaño, no andan alejados. Es preciso recalcar, el escaso aprecio que al "pluralismo político e ideológico y cultural", soporte de la Constitución Española de 1978, protegido y garantizado, pero no creado por élla, manifiestan los nuevos sacerdotes del culto constitucional o los nuevos intelectuales orgánicos y hegemónicos que han convertido al nacionalismo democrático vasco en un "otro" no integrado, ${ }^{21}$ o los han expulsado, trans Tiberim, con la «impropia y porosa categoría de la deslealtad constitucional". ${ }^{22}$

19. Reconfortan, empero, por rescatar la memoria liberal española, los esfuerzos de Juan MARICHAL, El secreto de España. Ensayos de Historia intelectual y politica, Madrid, 1995 y de Elías Díaz, Los viejos maestros. La reconstrucción de la razón, Alianza Universidad, Madrid, 1994. "Pensamiento español 1939-1973", Cuadernos para el diálogo Madrid, 1974, su clásico libro felizmente reeditado, Estado de derecho y sociedad democrática, Editorial Taurus, Madrid, 1998.

20. Santiago RAMÓN Y CAJAL, El mundo visto a los ochenta años. Impresiones de un arteriosclerótico, Espasa Calpe, Madrid, 2000. Las reflexiones de este aragonés nacido en el enclave navarro de Petilla de Aragón, imbuídas de cierto regeneracionismo costita, pueden leerse en las páginas 106 y ss. Anota Don Santiago cómo "deprime y entristece el ánimo el considerar la ingratitud de los vascos, cuya gran mayoría desea separarse de la patria común. Hasta en la noble Navarra existe un partido separatista o nacionalista robusto y bien organizado, junto con el tradicionalista que enarbola todavía la vieja bandera de Dios, Patria y Rey. En realidad, Euzkadi y Navarra constituyen de hecho feudos vaticanistas, y son perdurable amenaza de Guerra civil.. Si quieren leerse reflexiones de carácter étnico, pueden leerse las notas de Gustavo Búeno, De la fuerza de la razón. Nuevos estudios evolucionistas concernientes al origén, progreso, término y resurrección de nuestra especie, editado en Zaragoza en la Imprenta Gambón, en el año 1928, singularmente la parte dedicada al "pueblo vaco y el bereber como razas-testigos", pp. 109 y ss. Ni qué decir tiene que Don Gustavo BuENo, amen de buen médico, no era nada nacionalista.

21. Se comportan en muchas ocasiones como aquellos que describe Antonio Gramsci, en Quaderni dal carcere, Turin, Einaudi, 1977, III.

22. LaCASTA ZabalZa y Martínez de Pisón, Nacionalismo y crisis del Estado en AÑón, Bergalli, Calvo, Casanovas, Derecho y Sociedad. Ediciones Tirant lo Blanch, Valencia 1998, p. 95. 
Las razones arguidas son varias: que sus propuestas soberanistas o autonomistas, responden a un etnicismo que supone la sustitución de los derechos individuales por derechos colectivos, lo que nos reconduce a un problema de filosofía jurídica y moral, y desde el orden constitucional, que las propuestas soberanistas o independentistas de Galeusca, del nacionalismo vasco, catalán o gallego, reflejadas, por ejemplo en la llamada Declaración de Barcelona no tienen cabida en la Magna Carta Española. ${ }^{23}$

Se suscita desde el punto de vista de la filosofía moral y política que en el mundo vasquista o/y nacionalista, hunden sus raíces determinadas concepciones etnicistas de la nación, y que solamente en el dominio del campo constitucionalista se funda la nación como una estructura política nacida de la voluntad de los ciudadanos. ${ }^{24}$

Esta discusión se traslada a la académica dicotomía entre derechos individuales y derechos colectivos. ${ }^{25}$ Se alega, en mímesis de las controversias anglosajonas entre comunitaristas e individualistas, que en la cuestión vasca se encuentran, pugnan y reflejan dos concepciones contrapuestas sobre el orden social, la de los derechos individuales frente a la tesis del imaginario foral (derechos colectivos), de base historicista y sepultadores de los únicos derechos posibles. ${ }^{26}$

23. Las formaciones vasquistas, catalanistas o galleguistas, han formulado históricamente propuestas de articulación del Estado, desde planteamientos federalistas, cosoberanistas o fueristas, o en en algunos casos independentistas. De ahí que los orígenes de la llamada Declaración de Barcelona, hunden sus raíces en dichos fueros de pensamiento. Desde el punto de vista del nacionalismo vasco puede leerse Esteban AnTxustegi, Abertzaletasunaren Auzia: Independentzia ala Autonomia. Sabino Arana eta Bere Oinordekoak. Instituto Luis Elizalde-Ikaskundea. Bilbao, 1997. Puede leerse el estudio introductorio a la obra de Lus DE Elizalde, Países y razas. Las aspiraciones nacionalistas en diversos pueblos (1913-1914), Colección Textos Clásicos del Pensamiento Político y Social del País Vasco, UPV/EHU, Bilbao, 1999, pp. 11-68. Una visión distinta del Partido Nacionalista Vasco, en Santiago DF. PABLO, Ludger Mees, José A. Robríguez Ranz, El péndulo patriótico. Historia del Partido Nacionalista Vasco, I: $1985-$ 1936. Editorial Crítica, Barcelona, 1999. Recientemente, y desde posiciones "patrióticas", Julen ZABALO, Abertzaleak eta ezkertiarrak, Elkarlanean, Villatuerta, Navarra, 2000. Una visión limitada temporalmente, sobre el "pasado" del galleguismo, vasquismo y catalanismo, en los trabajos reunidos por Justo G. Beramendr y Ramón MaIz, Los nacionalismos en la II." República, Siglo XXI, Madrid, 1991.

24. Sobre otro de los mitos asentados imperialmente, la nación de ciudadanos, puede consultarse, Martin THOM, Repúblicas, naciones y Tribus, ediciones Trea S.L., Adrian Hastings, La construcción de las nacionalidades. Cambridge Universitary Press, Madrid, 2000. Recientemente se han publicado, diversos trabajos, bajo la edición de John HALl, el libro Estado y Nación. Ernest Gellner y la teoría del nacionalismo, Cambridge University Press, Madrid, 2000, con la significativa traducción de José María POrTillo y prólogo de Jon Juaristi. Una crítica interesante Pierre André TaguierF, "El nacionalismo de los nacionalistas. Un problema para la historia de las ideas políticas en Francia", en Gil DelanNOI y Pierre André TaguiefF, Teorías del Nacionalismo, Paidos, Barcelona, 1993, pp. 63 y ss. Son sugerentes las conversaciones de Guy Heraud recogidas en Hacia la abolición de las soberanías para la salvación de los pueblos (Conversaciones federalistas con Marc Lengerau), Oñati, 1989

25. Un resumen de la cuestión LÓpez CALERA, ¿Hay derechos colectivos? Individualidad y sociabilidad en la teoría de los derechos. Ariel Derecho, Barcelona, 2000, que reelabora alguna de sus tesis del opúsculo Nacionalismo ¿Culpable o Inocente? Editorial Taurus, Madrid, 1995.

26. Escribía con razón LACASTA-ZABALZA, Democracia y fuero navarro, Revista HIKA núm. 104, octubre de 1999 pp. 20-21, que «llevar la discusión foral a un enfrentamiento entre imaginarios liberales (laicos y avanzados) y no menos imaginarios carlistas (clericales y retrógrados) es un disparate histórico". La construcción del fuerismo navarro es fundamentalmente liberal (Iturralde y Suit, Serafín Olave, Hermilio de Olóriz, Arturo Campión) y republicano federal (Olave etc.) Los fueros son a la postre, también un concepto jurídico indeterminado. Los fueros "no son una especie de Constitución escrita y clara sino todo eso junto y más cosas. Los derechos históricos de la Constitución española los definen por su 
Ambas afirmaciones son igualmente míticas, si bien el escalpelo se ha dedicado más a viviseccionar el cuerpo del nacionalismo vasco, que la "mano invisible", del nacionalismo español. ${ }^{27}$

En estas mares jurídico-constitucionales, han de bogar las diversas propuestas formuladas por Miguel Herrero de Miñón, que se han ido desgranando en una serie de artículos y publicaciones, que han visto la luz a lo largo de veinte años. Uno de esos libros perturbadores, ha sido el escrito por Miguel Herrero de Miñón, Derechos bistóricos y Constitución, publicado en 1998 por una prestigiosa editorial madrileña. ${ }^{28}$ Este libro importante y controvertido, sigue la senda constitucional anticipada por Idea de los Derechos Históricos, ${ }^{29}$ se ha visto continuado por Estructura y función de los derechos bistóricos: Un problema y siete cuestiones, ${ }^{30} \mathrm{y}$ recientemente por su trabajo "Autodeterminación y derechos históricos", publicado como artículo del libro Derechos históricos y constitucionalismo útil. ${ }^{31}$ Recientemente ha compendiado su discurso en un breve trabajo titulado Qué son y para qué sirven los Derechos Históricos. ${ }^{32}$

La aparición de los trabajos de Herrero de Miñón, ha dado origen a toda una serie de críticas que más tienen de expresión de una auténtica purgatio canoni$c a$, que una reflexión crítica en el sentido kantiano, de las propuestas y de las tesis sustentadas por el autor ${ }^{33}$.

abstracción y correcta ubicación en el tiempo bastante bien. Pero son en realidad la suma de intereses concordantes, contrapuestos y antagónicos. Porque a los fueros pertenecía la supervivencia del euskera para Arturo Campión y los intelectuales de la Revista Euskara. Los montes comunales y la propiedad municipal de la tierra, el común, eran los fueros de la gente pobre y enemiga del injusto reparto de la propiedad agrícola por parte del liberalismo. Fuero es el carácter paccionado del Convenio económico de Navarra con el Estado español (artículo 45.4 del Amejoramiento del Fuero de 1982). Autogobierno público, democracia, eran los fueros para gente digna como el navarro Manuel Irujo, dirigente del PNV y ministro de Justicia de la Segunda República española. Aunque el fuero era y es también ese coto de caciques, liberales o carlistas según convenga, vascos de temporada, franquistas o de centro como hoy se estila, para el corte de bacalao al por mayor a favor de sus particularísimos intereses". Puede consultarse NIEVA ZARDOYA, La idea euskara de Navarra. 1864-1902. Bilbao 1999.

27. Si leemos los índices y los artículos de las, por otra parte estupendas revistas, Cuadernos de Alzate o Claves de Razón Práctica, veremos el predominio, o quizás en expresión mercantilista, el abuso de posición dominante, de las tesis contrarias no sólo al nacionalismo vasco, sino a todo aquello que suponga modificar o alterar las bases de la organización del Estado, singularmente, la cuestión de la soberanía, del soberanismo, o de la federación. Igual que el eslogan de SOS Racisme francés, "touche pas" .

28. El libro, Derechos históricos y constitución, Editorial Taurus, Madrid, 1998, recopila diversos artículos y materiales, publicados o expuestos en diversas publicaciones y foros, que se citan expresamente en la Nota Bbliográfica, obrante al la página 27 del libro.

29. Ediciones Austral 1991.

30. En el libro que recoge las ponencias del curso de verano de la UPV/EHU, coordinado por el propio Herrero y por Ernest Lluch, Foralismo, Derechos Históricos y democracia, y editado por la Fundación BBV, Madrid, 1998, pp. 323 y ss.

31. Corresponde a la segunda parte del estudio sobre los derechos históricos, en los Cursos de Verano de la UPV/EHU, celebrados en el verano del 98, cocrdinados por los mismos directores, y celebradas con el nombre de Derechos Históricos y constitucionalismo útil. Editado por la Fundación BBV, Madrid, 2000.

32. Publicado en la Revista Internacional de los Estudios Vascos, RIEV, 44, 2, diciembre de 1999, pp. 309-322.

33. Un ejemplo es Parada Vázquez, España: "¿una o trina" (Hacia el Estado de las Padanias de la mano de Herrero Rodríguez de Miñón)" en la R.A.P. núm. 141, pp. 7 ss. 


\section{UNA PRIMERA CIABOGA CRÍTICA: ¿HISTORICISMO O DEMOCRACIA ALBORAIQUE?}

Críticas reiteradas en la común opinión, se han vertido en relación con las propuestas de "compromiso y convivencia" constitucional articuladas en su discurso sobre la Disposición Adicional Primera de la Constitución Española de 1978. Hilo de Ariadna conductor de las mismas es la acusación velada y expresa del "historicismo", de "carlismo" y otra serie de epítetos de esa laya, que se utilizan, de modo simétrico, a la expresión español, que emplean algunos patriotas vascos. ${ }^{34}$

Sin embargo, reflexión histórica no supone caer en el historicismo constitucional. Supone adentrarse en una exégesis constitucional, efectuada a la luz de una perspectiva científico cultural, que permite, como señala Peter Häberle, «lograr mejores cotas de comprensión entre los textos jurídicos y sus respectivos contextos que la realizada hasta el presentem. ${ }^{35}$ Negar los elementos históricos o historicistas en el texto y en el contexto constitucional, como señala Herrero de Miñón, reduce la norma constitucional, ciertamente a mera norma jurídica opaca, y escasamente útil para una integración "política", o pensar que el sujeto constituyente ha creado la realidad "ex ovo", y las normas jurídicas devienen en categorías jurídicas huecas, meras carcasas positivas, como señalara Pashukanis. Sin embargo dicha acusación se realiza desde la "amnesia estructural" del texto constitucional de 1978.

Ha señalado Mary Douglass, que quien se «afana en pos de la verdad histórica no está intentando obtener una imagen más nítida de su propio rostro, ni tan siquiera una en la que salga más favorecido. La manipulación y reelaboración conscientes no constituyen más que un pequeño esfuerzo por remodelar el pasado. Al examinar de cerca cómo se construyen los tiempos pasados, nos damos cuenta de que en realidad dicho proceso tiene que ver muy poco con el pasado y muchisimo con el presente. Las instituciones crean lugares oscuros donde no se puede ver nada ni se pueden hacer preguntas (la imposibilidad de despedazar el Leviathan español). También hacen que otras zonas muestren una prolija precisión de detalles que se

34. Ignoro si el apelativo carlista es en sí mismo, peyorativo. Recientemente un conocido profesor universitario, autor de sugerentes Panfletos, acusaba a un dirigente del PNV/EAJ de haber pecado por tener un padre carlista. Los viejos principios liberales de la responsabilidad individual se veían trastocados, en nombre de la libertad, por la culpa sanguinis tribal. Que el argumento carlista se emplea, para relajar el pensamiento, parece algo más que evidente. La lectura del aggiornato Antonio Elorza, Hacia Otra Euskadi, El País (23-9-2000), corrobora esta intuición reiterada desde las páginas de opinión del Talmud de la cuestión vasca. Pero la versión del argumento carlista como argumento a fortiori de la escasa condición democrática del PNV o de EA, se hunde, también, en la amnesia estructural y geográfica. Si reparamos en la UPN -filial foral en Navarra del PP-, la mayor parte de sus fundadores y cuadros, eran ellos, no sus padres, carlistas, y dentro del carlismo, tradicionalistas. Baste citar a Del Burgo, Aizpun, Zubiaur. Y de AP-PP también: Oreja, Rabanera, Urqujo, etc. Cierto es que en el caso navarro, se da una mayor coincidencia en el origen ideológico de los cuadros populares, también hay importantes casos de dirigentes de origen falangista. En eso se parecen más a los dirigentes madrileños plagados en la actualidad de sonoros apellidos que recuerdan el BOE de los años cincuenta y sesenta.

35. Peter HäBERLE, Teoría de la Constitución como ciencia de la cultura, Editorial Tecnos, Madrid, 2000, p. 160. 
estudian y ordenan con municiosidad". La memoria pública, concluye, "es el sistema de almacenamiento del orden social". ${ }^{36}$

El concepto de amnesia estructural aplicado a la antropología social, puede aplicarse, mutatis mutandis, en la arqueología constitucional española. Es atinado el diagnóstico efectuado desde la Provincia, "el constitucionalismo español imperante ha acordado expulsar a la historia de sus reflexiones prescindiendo en el mismo movimiento de la menoria", aunque hay "gratificantes excepciones como las de Herrero de Miñón, Elías Díaz o Bartolomé Clavero".

Nos encontramos ante una democracia alboraique, como ha escrito en uno de los pocos libros que le despiertan a uno de la somnoliencia político-constitucional en la que estamos instalados, el Profesor Lacasta Zabalza, fruto de un pluralismo enteco $y$ desmemoriado. ${ }^{37}$

De ahí que en la academia perturben las voces, ancestrales o no, que desarrollan un discurso de construcción "útil y dúctil" (Zagrebelsky), y de integración política (SMEND) y no de mera glosa, cual mos italicus contemporaneo, de los textos constitucionales, y por ende, de la recurrente reflexión sobre el modo de organizarse las Españas, como es el desarrollado por el autor, en las diversas publicaciones antes citadas. ${ }^{38}$

De algún modo la crítica a las tesis y propuestas de Herrero de Miñón, quien así mismo se proclama, nacionalista españoly partidario de la España Grande, han venido de la mano de dos aparejos distintos: a) de la rancia concepción unitaria y uniforme de la nación española, ajena a la tradicición democrática española b) de las nuevas tesis -varias pero monocordes- del patriotismo constitucional, que practica, con ciertas dosis de mos italicus, la veneración del texto constitucional.

Ha de ser sorpendente que los arponeros de la obra sobre las relaciones entre el Leviatan Español y la Ballena vizcaina, estén todos enrolados en un mismo bistórico barco ballenero, que navega, como diría Julían Marías, desde hace quinientos años, en las aguas procelosas de la cantábrica y oceana mar. E incluso, a la vista del tono y del timbre de las críticas, se ha abierto una nueva página del Index Librorum Probibitorum, cuyos lomos, fierros y tapas, han sido encuadernados por artesanos dispares pero prestos - con la unanimidad que retrata Julio Verne en $E l$ Correo del Zar-, ante el asedio tártaro, calificando a su autor, cuando menos de relapso. Zaristas, nihilistas rusos, cosacos, discípulos de Herzen y ortodoxos, paneslavos u occidentalistas, devienen en rusos -como se ha de ser ruso- cuando de conjurar el peligro tártaro se trata, en una comunidad de opinión utilitaria, más que útil, que recuerda el pasaje de la Justicia de Almudevar de Braulio Foz.

¿Acaso los trabajos de Herrero de Miñón son un arpón en manos de un Acab foral dispuesto a desmembrar el Leviathan español? ¿Deberá el ilustre, pero relapso

36. Mary Douglas, Cómo piensan las instituciones, Alianza Editorial, Madrid, 1996., pp. 104-105.

37. Vide, nibil obstat; José Ignacio LACASTA-ZABALZA, España uniforme. El pluralismo enteco y desmemoriado de la sociedad española y de su conciencia nacional e intelectual, Editorial Pamiela, Pamplona-Iruña, 1998, pp. 340 y ss. y passim. La cita anterior corresponde al Prólogo del Libro, p. 11.

38. La función de la autonomía como integración política, está presente en el libro de Eduardo LLORENS, La autonomía en la integración política. La autonomía en el Estado moderno. El Estatuto de Cataluña, Edersa, Madrid, 1932. 
jurista, invernar tras las rejas de Monte Lupo, hasta que llegue su Canosa, y abandone el archipiélago de Padania?39

Procede olvidarnos del estado de la cuestión en la doctrina de la Adicional Primera de la Constitución, expuesta, sucintamente, por Arrieta Alberdi en el volumen Derechos Históricos y constitucionalismo útil, ${ }^{40}$ y centranos en otras reflexiones, o si se estima más adecuado en la crítica de la crítica a la obra de Herrero de Miñón, que entiendo de mayor endeblez, reconociéndome de antemano, según el sabio consejo del Profesor Óscar Alzaga, buérfano de interés alguno, hecho eso sí, desde las limitaciones dogmáticas de una asignatura vecina, como es la del derecho constitucional concretado. ${ }^{41}$

\section{DE ARPONES HISTÓRICOS Y DE LA COFRADÍA VASCA DE MAREANTES}

Se aduce, entre las críticas formuladas a la obra de Herrero de Miñón, que sus propuestas y tesis, introducen el fantasma del derecho bistórico (derecho colectivo) en un orden constitucional liberal. E incluso que la propuesta útil que efectúa del juego de la Adicional Primera de la Constitución y de la Adicional del Estatuto de Autonomía de Guernica, ${ }^{42}$ introduce en el seno del poder constituido un nuevo sujeto constituyente, en forma de cosoberanía, soberanía compartida, confederación o fómulas constitucionales de ese tenor. ${ }^{43}$

Las críticas subrayan que la introducción en el debate constitucional de la singularidad de los Cuerpos politicos forales, como fragmentos de estado en la propuesta de HerRero de MiÑón, no solo desguazan el principio de indivisibilidad de la soberanía, sino que al crear un nuevo sujeto constitucional, y constituyente, se desplaza la soberanía cívica a una soberanía de naciones. ${ }^{44}$

39. La discusión de los constitucionalistas con las tesis del autor, y también con el autor, me traen a la memoria un cuentito de Ambrose BIERCE, titulado El Cangrejo y su Hijo. Reza la fábula del Gringo Viejo, así: Un cangrejo lógico le dijo a su bijo: -¿Por qué no caminas de frente? Tu manera de andar de lado resulta particularmente desagradable. -¿Por qué no caminas de frente tú también?- replicó el Hijo.Joven errado - replicó el Cangrejo Lógico- estás introduciendo argumentos nuevos que nada tienen que ver, Tomado de Ambrose Bierce, Fábulas fantásticas, El Club Diógenes. Valdemar, Madrid, 1999, p. 146.

40. Jon ARrietA ALBERDI, "Las imágenes de los derechos históricos: un estado de la cuestión", en Derechos Históricos y constitucionalismo útil, pp. 225 y ss, resume sucintamente las diversas tesis enfrentadas en estas nuevas disputationes.

41. Leáse Óscar Alzaga, "Nota preliminar. Sobre la actitud de nuestra Revista ante los debates científicos y los dictámenes de parte", en el número 3 de la Revista Teoría y Realidad Constitucional, 1999, pp. 9-11.

42. Presente en Derechos bistóricos y constitución, y desarrollada en Autodeterminación y derechos históricos, ob. cit., pp. 213 y ss.

43. Sobre el concepto de soberanía, Hermann Heller, La soberanía. Contribución a la teoría del derecho estatal y del derecho internacional, FCE. México, 1995. Y los trabajos reunidos por Roberto Bergalli y Eligio Resta, Soberanía: un principio que se derrumba. Aspectos metodológios y juridicopolíticos. Editorial Paidos, Barcelona, 1996, Luigi Ferajol, Derechos y garantías. La ley del más débil, Editorial Trotta, Madrid, 2000, pp. 125 y ss.

44. Recoge la consideración de los territorios históricos como fragmentos de Estado, en el capítulo VIII y IX del Libro, Derechos históricos y Constitución, pp. 159 y ss. Provienen sus reflexiones de 
Si este fenómeno se produce en el orden constitucional, desde la filosofía de los derechos civiles y políticos, se utilizará un argumento complementario. La propuesta da pábulo -se dirá- a la reviviscencia de una nación bistórica, frente a la arquitectura de un orden constitucional liberal que descansa en la nación de ciudadanos y en la protección y garantía de los derechos individuales, de suerte que serán los territorios los libres y no los ciudadanos. ${ }^{45}$

Esa será una de las críticas que se hacen -curiosamente desde la historia- a los trabajos de Herrero de Miñón ${ }^{46}$. Con cierta socarronería, ignoro si étnica o liberal dada su condición de escocés y miembro del Scottish National Party, partidario de la autodeterminación escocesa, escribe Neil MacCormick, que la "verdad respecto a los seres humanos es que sólo pueden llegar a ser personas -tener conciencia de su propia individualidad-como resultado de sus experiencias sociales en las comunidades bumanas, dado que la persona es tanto un producto de la sociedad como a la inversa. Incluso el individualismo político es un programa de organización social". ${ }^{47}$

Ignoro si la cuestión de los derechos colectivos frente a los derechos individuales, es en ocasiones, más cuestión de geografía que de dogmática. ${ }^{48} \mathrm{La}$ discusión está servida, y en algunos rasgos recuerda la gran perturbación de la discusión sobre la naturaleza y los derechos de los indios, abordada por Fernández Buey y Subirats, de manera elocuente. ${ }^{49}$

Los Territorios Históricos como fragmentos de Estado en el volumen, Los derechos bistóricos vascos, IVAP, Oñati, 1988, donde amplía alguna de sus impresiones plasmadas en su "Prólogo" a la obra de JELLINEK Fragmentos de Estado, Editorial Civitas. Madrid, 1978, en "Concepto y función de los Derechos Históricos (Disposición Adicional I. " de la Constitución", en la Revista de las Cortes Generales. Reitera sus tesis, en "La titularidad de los derechos históricos", R.E.P. núm. 58 (1987) y que reproduce en el volumen dirigido por Gómez-Ferrer Morant, Libro Homenaje al Profesor José Luis VIllar Palasí, Civitas, 1989. Refunde todas sus opiniones, en la excelente monografía Idea de los derechos históricos en la Colección Austral, Espasa Calpe, Madrid, 1991. Se recupera, como fragmentos de monarquia, en Fuerismo liberal, Prólogo al Volumen II, preparado por Juan VIDAL-ABARCA, Federico de VerásTEGUI y Alfonso DE OTAZU, Fausto de Otazu a Iñigo Ortés de Velasco. Cartas 1834-1841. Volumen 2. Vitoria-Gasteiz, 1995.

45. Son de interés las reflexiones de TOSCANO MÉndez, "Nacionalismo y pluralismo cultural. Algunas consideraciones, y ¿Democracia de los ciudadanos o democracia de las nacionalidades?”, en el volumen dirigido por el propio Toscano, Rubio CARracedo, y José María Rosales, Ciudadanía, ob. cit., pp. 71-86, y 87-115, específicamente sobre la cuestión vasca, pp. 90 y 91

46. Puede verse el trabajo de CuEnCa Toribio, "Notas historiográficas a una polémica sobre España: M. Herrero de Miñón- Ramón Parada", Revista de las Cortes Generales, pp. 48 y ss.

47. Neil Maccormick, Derecho legal y socialdemocracia, Editorial Tecnos, Nadrid, 1990, p. 197. Puede leerse su reciente ponencia en la Jornadas Internacionales, sobre Justicia y Autogobierno, organizadas por el ISIJI Oñati. En San Sebastián, los días '11 y 12 de febrero del 2000. Sobre estos extremos son de enorme interés las reflexiones de Stephen Holmes, Anatomía del Liberalismo. Alianza Editorial, Madrid, 1999, pp. 235 y ss.

48. Desconozco cual sería mi reacción si fuere indio mapuche, y como tal, y no como un mero quatenus, reducido a la condición sociologica o antropológica de población, y viera los territorios comunales apropiados por la teoría individual, de la ocupación colonial que deriva de la aplicación del vigente Código Civil Chileno. La lectura de los informes y estudios sobre la persecución colectiva de los mapuches por su misma ipsiedad, que diria JankélÉvITCH (Cfr. Lo imprescriptile. ¿Perdonar con honor y dignidad? Muchnik Editores, Barcelona, 1987) es estremecedora. Leáse a ese respecto, The Ecologist, núm. 425, julio 200. Lo mismo acontece con otros pueblos indígenas de América. No es de extrañar que Xabiert RuBERT DE VENTós, De la identidad a la independencia: la nueva transición, Editorial Anagrama, Barcelona, 1999, pp. 39 y ss. haya puesto el dedo en la llaga en ese sentido.

49. Francisco FERNÁNDEZ BUEY, La gran perturbación. Discurso del indio metropolitano. Ensayos Destino, Barcelona, 1995, y Eduardo SuBiRATs, La conquista del Nuevo mundo y la conciencia moderna. 
Cierto utilitarismo escocés me llevaría a predicar la mutua interdependencia de unos y otros (Individuum und Gemeinschaft), dado que "requisito del derecho individual es el colectivo. Legitimación del derecho colectivo es el derecho individual. La predicación es mutua.${ }^{50}$ En el dominio constitucional, como veremos, la Adicional Primera de la Constitución de 1978, reconoce y ampara los "derechos históricos de los territorios forales", que se ven reflejados en los dos Estatutos de Autonomía de la Vasconia peninsular, la Adicional Primera del Estatuto de Guernica y la Adicional Primera del Estatuto Navarro o Amejoramiento del Fuero. ${ }^{51}$

Anaya \& Muchnik, Madrid, 1994, están llenos de sugerencias. O como en ocasiones los mal llamados derechos colectivos, su garantía y protección, devienen más garantistas y eficaces para la protección de la persona humana en su ipseidad, y no como mero quatenus (eurocéntrico, para más señas). De cómo las tesis modernas resultaron, a nuestros ojos, más reaccionarias que las medievalizantes, sobre la protección, dignidad y derecho de los indios, puede verse en la lectura de Francisco de VITORIA, Sobre el poder civil, sobre los indios, sobre el derecho de la guerra, Editorial Tecnos, Madrid, 1998, que recopila parte de sus tratados clásicos. La controversia de LAS CASAS y SEPúlveda, uno medieval otro moderno, en PÉrez LuÑo, La polémica sobre el Nuevo Mundo. Los clásicos españoles de la Filosofía del Derecho, Editorial Trotta, Madrid, 1992. Los trabajos que abordan la situación actual, del conflicto comunidades indias versus derecho europeo liberal, son extensos. Sobre los nuevos problemas del multiculturalismo jurídico, sin ánimo de agotar esta veta, los trabajos recopilados por Jesús ConTreras, La cara india, la cruz del 92. Identidad étnica y movimientos indios.Editorial Revolución, Madrid, 1988. Y Luigi FERRAJOLI La conquista de América y la doctrina de la soberania exterior de los Estados, en BERGALLI y RESTA, Soberanía, ob. cit. pp. 145 y ss. y Carlos María CárCova, La opacidad del derecho, editorial Trotta, Madrid, 1998, pp. 61 y s. Una visión crítica desde el paradigma ilustrado, Juan José SeBrelLI, El asedio a la modernidad. Critica del relativismo cultural. Editorial Ariel, Barcelona, 1992, pp. 281 y ss. El provocador libro de SEBRELl no resuelve, la colonización jurídica de un derecho opaco, que reformula el principio de igualdad: todos los hombres somos iguales, a condición de que usted sea igual que yo, o sin serlo, se asimile a mi comunidad ilustrada imaginada. Lo había apuntado John Stuart MIL, en Del gobierno representativo, Editorial Tecnos, Madrid, 1994, pá. 185, en los siguientes términos: unadie puede dudar de que no sea más ventajoso para un bretón o para un vasco de la Navarra francesa ser arrastrado en la corriente de ideas y de sentimientos de un pueblo altamente civilizado y culto -ser miembro de la nacionalidad francesa, con todos los privilegios de un ciudadano francés ... que vivir adheridos a sus rocas, resto semisalvaje de los tiempos pasados, girando sin cesar en su estrecha órbita intelectual, sin participar ni interesarse en el movimiento general del mundo". A la postre el discurso cívico de las naciones estado realmente existentes, recuerda la justificación de la conquista y la ocupación, descritas en la polémica citada, en la "minoría de edad" de los "buenos salvajes". A este respecto, Fernández Herrero, La utopía de América. Teoría. Leyes. Experimentos. Editorial Anthropos, Barcelona, 1992. Los nuevos "menores de edad", en cosmopolitismo, son las minorías nacionales no asimiladas.

50. Bartolomé ClAVERO, "Derechos humanos (individuales) y derechos históricos (colectivos)", en Derechos históricos y Constitucionalismo, ob. cit., pp. 76. E in extenso, la lucidez de Clavero se vierte en Happy Constitution. Cultura y lenguas constitucionales, Editorial Trotta, Madrid, pp. 237 y ss. Sin ánimo de ser exhaustivo, puede rastrearse esa polémica, en los diversos trabajos recopilados por RuBIO Carracedo, Rosales, Toscano MÉndez, Ciudananía, nacionalismo y derechos bumanos, Editorial Trotta, Madrid, 2000, Rainer BAuBÖK, Justificaciones liberales para los derechos de los grupos étnicos, en Soledad GARCía y Steven LuKes, (Comps.) Ciudadanía: justicia social, identidad y participación, Editorial Siglo XXI, Madrid, 1999. Son de enorme viveza los apuntes de Michael MANN, "La cara oculta de la democracia: la limpieza étnica y política como tradición moderna", en el monográfico de la New Left review, núm. 1 (El nacionalismo en tiempos de globalización).

51. Sobre la Adicional del Amejoramiento, GonZÁlez NAVArro en SANTAMARia Pastor, Comentarios al Estatuto de Autonomía de la Comunidad Autónoma de Navarra, MAP, Madrid, 1992, pp. 767 y ss, y en "Navarra y el Tribunal Constitucional" en MarTín-Retortillo, S., Derecho Público Foral de Navarra. El amejoramiento del fuero, coedición Editorial Civitas, Gobierno de Navarra, Madrid, 1992, pp. 698 y ss, en el mismo volumen, MuÑoz MACHADO, "La Disposición Adicional Primera de la Constitución"; pp. 298 y ss; un intento de racionalización de los "derechos históricos navarros", en RAzQUIN LizARRAGA, Fundamentos Jurídicos del Amejoramiento del Fuero. Derechos Históricos y Régimen Foral de Navarra, Gobierno de Navarra, 1989. Una visión crítica en LopereNA RoTA, Aproximación al régimen 
Resulta, empero irrelevante la discusión dogmática sobre el concepto de nación, si el Renan demócrata del plebiscito cotidiano, si las teorías contractualistas de la sociedad si el patriotismo constitucional de Habermas ${ }^{52}$, que exige, como apuntara Rosales, una "reapropiación crítica del pasado", mientras que en orden constitucional español, se ha partido de una voluntaria "amnesia estructural" por la clase hegemónica ${ }^{53}$. Me resultan más relevantes otras concepciones de la nación española más asentadas en una comunidad imaginada, y que trufan, todavía los libros de textos escolares ${ }^{54}$.

Lo cierto es, y con ese dato cuenta Herrero de Miñón, que hay una significativa y relevante Cofradía de mareantes de ciudadanos vascos, que, no reconoce el derecho del Estado a disponer de ellos, de su población sin su consentimiento, como apuntara Ignacio A. Dorronsoro ${ }^{55}$. Reflejos en ocasiones, que nos remontarían a terri-

foral de Navarra, IVAP, Onati, 1984, ampliada, en "Unidad constitucional y actualizaciones generales y parciales de los Derechos Históricos", en el volumen colectivo Jornadas de Estudio sobre la actualización de los derechos históricos vascos", UPV, Bilbao, 1986, pp.310 y ss, en "El mito foral" en el número 2 del Boletín del Instituto Gerónimo de Uztáriz, Pamplona-Iruñea, 1988, pp. 55 y ss. y en Derecho bistórico y régimen local de Navarra, en Gobierno de Navarra, Pamplona, 1988.

52. Vease a este respecto, Jürgen Häßrermas, Más Allá del Estado nacional, Editorial Trota, Madrid, 1997, La constelación posnacional, Ensayos Políticos. Paidos, Barcelona, 2000, El Estadonación europeo y las presiones de la globalización, en New left review, núm.1, pp. 121 y ss. Una exposición reciente de las tesis en Marta Rodrícuez. Fouz, Espacio público europeo y patriotismo constitucional en Habermas, Cuadernos de Alzate, núm. 22, 2000, pp. 65 y ss.

53. José María Rosales, "Sobre la idea de patriotismo constitucional", en Rubio Carracido, y otros, Ciudadania, ob. cit. pp. 133 y ss.

54. Así el estudio de Álvarez Osés, Cal freire, Haro Sabater, González Muñoz, "La guerra que aprendieron los españoles. República y guerra civil en los textos de bachillerato (1938-1983)", Los Libros de la Catarata, Madrid, 2000, y con mayor generalidad, MArTínez TórTola, La enseñanza de la bistoria en el primer bachillerato franquista (1938-1953), Editorial Tecnos, Madrid, 1996. Su lectura permite, como diría Esther MARTínez, percibir las influencias ideológicas e historiográficas, de bastantes textos sobre la historia nacional trastocados en historia de la vida privada de ciudadanos.

55. Citado por lacasta Zabalza y Martínez de Pisón, ob. cit., p. 88. La obra de I. Álvarez Dorronsoro, Diversidad cultural y conflicto nacional, Editorial Talasa, Madrid, 1993. Repárese que el pensamiento "republicano" reduce a los pueblos, a poblaciones, salvo el imaginarium del ciudadano que en la vecina Francia, era, además una pequeña minoría franca y burguesa que tenía el francés como lengua, frente a la inmensa mayoría de "súbditos" que hablaban otras lenguas distintas. Eso sí, la República Francesa, durante el siglo XIX se dedicó a construir ciudadanos como los gentilhommes de L'île de France, con dos bases: la Escuela y el Ejército. Lo explica con tranquilidad Régis Deibray, El civismo explicado a mi bija, Muchnik Editores, p. 32: "La población es el conjunto de la gente que vive en Francia con o sin derechos políticos. El pueblo, en cambio, es una persona jurídica; es la reunión de los ciudadanos que se determina en el silencio de las pasiones (siempre que sea posible) y el secreto de su conciencia (secreto, personal y libre, como la pepeleta impresa que meten en la urna). Una población es una fotografía; un pueblo es una película, porque tiene una dinámica, con una historia y un suspense. El Pueblo no es un conglomerado de etnias, ni se confunde tampoco con la masa, la multitud, la muchedumbre. Ni con una clase de réprobos, por muy simpática que sea -populacho, plebe o currantes-. Hay una población corsa; pero en república no puede haber un pueblo corso; ni bretón, ni provenzal. El pueblo no se divide; es la nación al completo". Da buena cuenta de este concepto de nación de ciudadanos un hecho histórico, y no comunidad imaginada. Cuenta Marcel Lachiver, Vins, vignes et vignerons. Histoire du vignoble français, Fayard, 1988. como en la revuelta de los viticultores provenzales y languedocianos, en los primeros años de este siglo, en plena crisis vinícola, las tropas militares acantonadas se negaron a reprimir a los manifestantes, dado qué eran de leva obligatoria, y de la zona, y hablaba la tropa, las lenguas de poblaciones (occitanas y catalanas), mientras que la oficialidad, era "pueblo", que no población, y hablaba en francés. Ha señalado Lachiver, ob. cit., p. 474, al glosar la revuelta campesina del Languedoc: "...Bien sûr, les participants, dans les manifestations, s'exprimèrent en langue d'oc ou en catalan, mais il 
torios más abruptos, la diferencia de raíz en la división de Benjamin Constant entre la libertad de los modernos y la libertad de los antiguos, o entre la democracia roussoniana y la liberal. ${ }^{56}$

\section{LOS MAPAS DE NAVEGACIÓN DE LA CONSTITUCIÓN ESPAÑOLA DE 1978. UNA CARTOGRAFÍA HISTORICISTA EN EL CUADERNO DE BITÁCORA CONSTITUCIONAL}

La pregunta ha de ser otra. ¿Puede predicarse que el texto Constitucional Español de 1978 esté libre del argumento y del uso del derecho histórico? ¿No existe otra constitucionalización simbólica o mítica de derechos históricos que la Adicional Primera de la Constitución? Nada más lejos de la realidad constitucional, "realmente existente" (Bähro). Lo cierto es que como ha demostrado "ad nauseam", Xacobe Bastida, en su tan expléndido como ninguneado libro, La nación española y el nacionalismo constitucional, el artículo $2 .^{\circ}$ de la Constitución Española de 1978 está más cerca de la "nación histórica" que de la "nación de ciudadanos".57

A pesar de la dieta de historicismo predicada por Don Manuel García Pelayo, lo cierto es que la lectura del "papel constitucional", nos depara sorpresas escasamente cívicas. Si el preámbulo constitucional identifica al sujeto que era constituyente, sin saberlo, la "nación española", preconstiuída históricamente, los restos de historicismo trufan el texto constitucional.

Baste señalar el artículo $1 .^{\circ}$, que identifica un sujeto constitucional preexistente (España), al titular de la soberanía (el pueblo español), y a la Monarquía (preconstitucional). Es la "nación española" quien proclama su voluntad de "proteger a todos los españoles y pueblos de España en el ejercicio de los derechos humanos, sus culturas y tradiciones, lenguas e instituciones", y el el "pueblo español" quien ratifica el texto constitucional..$^{58}$

faut bien se rendre compte, qu'au debut de ce siècle, le français n'était pas encore d'un usage courant dans toutes les campagnes, surtout parmi les classes d'âges qui n'avaient pas fréquenté les écoles de la Republique». La consecuencia fue clara: los soldados provenzales fueron envados a Bretaña (Breizh), y los bretones a Provenza. Se hizo pueblo francés.

56. Sobre esta diferencia, los breves apuntes de Enzo SCIACCA, Interpretación de la democracia, Edersa, Madrid, 1994, pp. 99 y ss. y passim. y en RuBIO CARRACEDO, ¿Democracia o representación? Poder y legitimidad en Rousseau, Centro de Estudios Constitucionales, Madrid, 1990, passim.

57. Xacobe BASTIDA, La nación española y el nacionalismo constitucional, Madrid, 1998, totum. En la misma línea su trabajo bucanero, "Ortega y el Estado", Cuadernos Electrónicos de Filosofía del Derecho. núm. 1. Otra intepretación en PRIETO DE PEDro, Cultura, culturas y constitución, Centro de Estudios Constitucionales, Madrid, 1993, pp. 101 y ss.

58. Con cierta somardería Michel MANN, La cara oculta, ob. cit., pp. 25 y ss. al glosar el texto constitucional americano "nosotros el pueblo de los Estados Unidos", señala "a mi modo de ver, no es tanto el individuo desencarnado como los grupos, especialmente las clases sociales lo que resulta central para el liberalismo (...) Obviamente el pueblo no fue en realidad quien decretó y fundó la Constitución americana. Quienes la redactaron fueron cincuenta y cinco caballeros blancos de mediana edad, todos ellos propietarios y del más alto rango, encerrados durante dos semanas en Filadelfia. Afirmaban representar el pueblo de las trece colonias. Pero ¿quién era exactamente ese nosotros, el pueblo? Los padres fundadores no pretendían incluir ni a las mujeres ni a los esclavos ni a los nativos americanos. La mayoría de ellos no quería incluir a los varones blancos sin propiedad; en otras palabras, a las clases bajas. Los políticos 
El ya citado artículo $2 .^{\circ}$ declara, a la manera orteguiana, sin paliativos que esa patria histórica es indivisible, encomendando a las Fuerzas Armadas, garantizar "la soberanía e independencia de España defender su integridad territorial", la cartografía del poder (art. 8. $^{\circ}$ ), si bien, se introduce, melancolía quizás de la revolución francesa, el deber y derecho de los españoles de defender a España (art. 30), frente a esos trasnochados historicismos vascos de la exención de la soldadesca y de la conscripción obligatoria, que recurren incluso al Arbol Malato, para justificar el porcentaje de objetores e insumisos que dan las dos Vasconias. ${ }^{59}$

La lengua oficial del Estado -dato histórico preexistente- es el castellano, lengua estatal, en la acepción acuñada por Benedict Anderson, ${ }^{60}$ exigiéndose de los ciudadanos, el "deber de conocer" y reconociendo el "derecho de usar", declaración que se acompaña de una limitada declaración de cooficialidad en las reservas aborígenes autonómicas (art. 3.2.). ${ }^{61}$

En el dominio de los signos del Leviathan, se constitucionaliza una bandera representación de la monarquía histórica -con el límite de su propia creación voluntas regni- frente a la representación icónica de la enseña de la nación en armas, a los sones del Himno de Riego. Extravagante al texto constitucional, el Himno de la nación histórica, huérfano de letra, no es sino una Marcha de granaderos reales, cuya partitura arreglada hubo de ser adquirida por el Estado, manteniendo temporalmente un canon de explotación, sin que hasta la fecha, la letra "histórica" de Pemán, se haya fundido con el papel pautado constitucional. ${ }^{62}$

británicos de la época fueron más explícitos y distinguieron entre el pueblo y la plebe». En nuestra arqueología constitucional liberal, dada la construcción decimonónica de España como nación, se produce por vez primera, la integración forzosa en el concepto nacionalista de pueblo español, de los antiguos pueblos peninsulares. Veáse Americo CASTRO, Sobre el nombre y el quien de los españoles, Madrid, 1985, passim, y La realidad histórica de España, Editorial Porrúa, México 1987. Y ÁLVAREZ Junco, La nación en duda en Pan-Montojo (Dir.) Más se perdió en Cuba, España, 1898 y La crisis de fin de siglo, pp. 405 y ss. La concepción nacional del pueblo español, deudo malo del concepto de ciudadanía francesa, reduce a meras "poblaciones" a vascos, catalanes gallegos o aragoneses. Paradójicamente el concepto liberal y nacionalista de pueblo español, decimonónico, integra forzosamente la condición de aragonés o de vizcaíno o navarro, disolviendo ope legis, su misma ipsiedad en un concepto normativo derivado de un arquetipo -el español- imaginado. La labor del Estado Español será crear españoles, como reflejo de una comunidad imaginada - de un tipo predeterminado- como fuera en la vecina Francia.

59. Veáse C. COEllo MARTín, La disposición adicional primera, pp. 157 y ss. Sobre la significación del "árbol Malato", en CARO BAROja Sobre el árbol de Guernica y otros árboles con significado jurídico y politico, en Ritos y Mitos Equívocos, Ediciones ISTMO, Madrid 1989, pp. 353 y ss. Se ha abierto ese camino en EsparZa Zabalegui, Abajo las Quintas. La oposición histórica de Navarra al Ejercito español, en Ed. Txalaparta. Tafalla, 1994. Una peculiar visión de la insumisión en clave foral. No es tan de extrañar. Reflexiones sobre la función del ejército en los problemas de las nacionalidades en el caso español, fueron puestas de manifiesto por los conocidos etnicistas, Karl MARX y Federico ENGELs, entre otros, en el artículo publicado en 1873, en Der Volksstaat, "La república en España", recopilado en Pedro RuBAs (Editor), Escritos sobre España. Editorial Trotta-Fundación de Investigaciones Marxistas, Madrid, 1998, pp. 240-244.

60. Benedict ANDERSON, Comunidades imaginadas. Reflexiones sobre el origen y la difusión del nacionalismo, Fondo de Cultura Económica, Madrid, 1993, pp. 68 y ss.

61. Los derechos lingüísticos de los catellanoparlantes se defienden y garantizan desde el ius soli y desde el ius sanguinis. Los de los hablantes de lengua vasca, gallega y catalana ( sin entrar en otras riquezas lingüísticas), con una aplicación limitada, autonómicamente, del ius soli.

62. Veáse los RRDD 1543/1997, y 1560/97 de 3 y 10 de octubre, y el RD 2027/98 de 18 de septiembre, sobre adquisición por el Estado ade los derechos de explotación de determinadas obras musicales y encomienda de su actuación al Ministerio de Educación y Cultura". 
A la condición histórica de español, como nacional propio, suman restos de la melancolía, que diría Juaristi respecto al nacionalismo (vasco, por supuesto), de la hispanidad imperial (arts. 11.3 y 13 y art. 56.1).

Retórica vana los convenios de doble nacionalidad, a la vista de la condición bárbara (extranjeros) de los hijos de la Madre Patria, en la praxis administrativa en el dominio de la extranjería, y las galernas inconstitucionales que se avecinan con el Proyecto de nueva Ley de Extranjería, auspiciado por el Ministerio del Interior, tras el bochornoso espectáculo gubernativo y parlamentario de la aprobación de la Ley vigente.

La propia mayoría de edad, queda salvada por la enmienda foral aragonesa (art. 12 Disposición Adicional 2. ${ }^{a}$ de la Constitución). Si todos los españoles somos iguales ante la ley, cual proclama el artículo 14, Las Partidas se integran como "cultura constitucional" en la STC 126/97 de 3 de julio, y a la manera de un ballenero clásico, Orwell, resulta, como en Animal Farms, que algunos son más iguales que otros. La Sentencia introduce el "derecho histórico nobiliario", como subsistema cultural jurídico que altera dicho derecho fundamental. ${ }^{63} \mathrm{El}$ multiculturalismo español, sigue siendo, como diría Americo Castro, razón de casta. O la proclamación realizada en el artículo 139 de la igualdad en derechos y obligaciones en todo el territorio del Estado, se cuartee en el dominio linguïstico. ${ }^{64}$

Si Benito Juárez se quejaba en frase repetida, del pobre Méjico tan lejos de Dios y tan cercano a los Estados Unidos, lejano nos parece, también, al concepto de nación de ciudadanos, el artículo 16, cuya sustancia histórica ha desentrañado

63. Mientras escribo estas apostillas llega a mis manos la STS de 11 de mayo del 2000 (Ar. 3408. Ponente: Sr. Martínez-Calcerrada), por la que se resuelve un conflicto relativo al orden sucesorio de los títulos nobiliarios. Sabido es que el Tribunal Supremo que venía aplicando las reglas generales de la herencia y la aplicación en el orden sucesorio del principio de igualdad y no discriminación por razón de sexo, tuvo que modificar su atinada doctrina, por la Sentencia del Tribunal Constitucional de 3 de julio de 1997, inexplicable a todas luces, y que llegue a afirmar, sin que nada ni nadie tremolen, que «resultaría paradójico que el título de nobleza pudiere adquirirse por vía sucesoria no tal y como es y ha sido históricamente según los criterios que han presidido las anteriores transmisiones, sino al amparo de criterios distintos" y en especial se subraya, "no siendo discriminatorio y por lo tanto inconstitucional el título de nobleza tampoco puede serlo dicha preferencia (del hombre sobre la mujer), salvo incurrir en una contradicción". Si aplicamos la doctrina constitucionalista del legislador negativo en otros órdenes de institutos jurídicos, privados y públicos, engarzados directa o indirecta con derechos fundamentales (igualdad, etc.), las consecuencias serían concluyentes: ni los derechos fundamentales son invocables en las relaciones entre particulares, (asunto Alarde de Hondarribia e Irun) ni los derechos y principios constitucionales -en tronco garantista- son aplicables en aquellos supuestos en los que exite un orden privado autónomo inmune, incluso en el dominio de institutos básicos del derecho civil, como es la herencia, dado que el propio orden constitucional amparaba sistemas multiculurales en su seno, en este caso el orden nobiliario autónomo. Sobre la aplicación de los derechos constitucionales en el dominio de las relaciones privadas, GuTiérREz GuTIÉrREz, "Criterios de eficacia de los derechos fundamentales en las relaciones entre particulares". Teoría y Realidad constitucional, n. ${ }^{\circ}$ 3, 1999, pp. 193 y ss. ¿Proscribiría el chador en la Escuela Pública el Constitucional en tanto que orden privado autónomo? $\mathrm{O}$ acaso, tan cercano a la corte, como alejado del igualitarismo vasco, haya olvidado que la ficción jurídicò-histórica de la hidalguía universal protegía mejor, los derechos de los súbditos de la Corona, que el sufragio universal censitario.

64. Dado el principio de territorialidad de los derechos fundamentales y de configuración legal, un catalán viviendo en Cuenca tiene menos derechos lingüísticos que un conquense viviendo en Barcelona. 
recientemente José Martínez de Pisón, y que pone en solfa, materialmente, la invocada aconfesionalidad del Estado. ${ }^{65}$

De la enseñanza y de su administración prestacional, consagrada en el artículo 27 , ha de predicarse que consagra un "principio de subsidiariedad", similar al esgrimido en la pugna medieval para justificar la ausencia de competencias del Estado en el orden educativo y su atribución natural a la única sociedad perfecta, la Iglesia católica, preexistente como cuerpo político propio del orden medieval.

$\mathrm{Al}$ orden histórico corresponde singularmente, el Título II de la Constitución ( $D e$ la Corona, artículos 56 a 65). Expresamente el título constitucional declara al actual monarca como "legítimo heredero de la dinastía histórica", extremo este que no hubiere gustado a Melchor Fernández Almagro, ${ }^{66}$ y que permite olvidar cual fue la legitimidad de origen de la dinastía instaurada por la Dictadura del general Franco,

65. José MARTínez de.PISÓn CAVEro, Constitución y Libertad Religiosa, Editorial Dykinson, Madrid, 2000. Símbolos y gestos son importantes en el orden constitucional, como ha señalado LUCAS VERDÚ. Las normas constitucionales son normas jurìdicas, pero no sólo son eso. ¿Se imaginan los arreboles que hubiere ocasionado si el Presidente del Gobierno Vasco hiciere una ofrenda en nombre de Euskadi, a San Miguel en Aralar, patrono de Vasconia y leyera un discurso de política general en la parroquia navarra? Los arponeros del Leviathan español hubieren acudido prestos a arponear la extinguida ballena vizcaína. Sin embargo, el Presidente de Navarra, Sr. Sanz, el 24 de septiembre del 2000, preso en un nuevo ejemplo de cesaropapismo, la "tradicional ofrenda del Gobierno de Navarra a Santa María La Real", pidiéndole a la Virgen "el cese de la sin razón de la violencia que sufrimos y nos aflige cada día". Tras el discurso -sigue la crónica del períodico pamplonés, Diario de Noticias (25 de septiembre del 2000 , día de San Formerio), el presidente entregó una cantidad simbólica de 300.000 pesetas "para el mantenimiento del culto, contenida en una de las urnas de plata utilizadas por las antiguas Cortes de Navarra. La parte musical del acto corrió a cargo de la Capilla de Música de la Catedral, bajo la batuta de (...). el conjunto coral comenzó entonando Salve virgen bella, una pieza del siglo XVIII, y concluyó con el Minueto de la marcha al Reyno. Además, al acto acudió el acompañamiento propio de los actos solemnes: maceros, rey de armas y banda de trompetas y clarines.". ¿Guarda alguna relación con Lewis CARROLL la puesta en escena?

66. Si la sucesión nobiliaria es un subsistema jurídico, la legitimación de la dinastía reinante en España, sería ajena al "orden monárquico". Máxime cuando la "nación de ciudadanos", representada en las Cortes Constituyentes aprobaron el Acta Acusatoria contra Don Alfonso de Borbon Hasburgo-Lorena, dictando sentencia condenatoria, en uso de su soberanía. Según el texto publicado en la Gaceta de Madrid, del 28 de noviembre de 1931, "Las Cortes Constituyentes declaran culpable de alta traición, como fórmula jurídica que resume todos los delitos del acta acusatoria, al que fue Rey de España, quien, ejercitando los poderes de su magistratura contra la Constitución del Estado, ha cometido la más criinal violación del orden jurídico de su país, y en su consecuencia, el Tribunal soberano de la Nación declara solemnemente fuera de la Ley a D. Alfonso de Borbón y Hasburgo-Lorena. Privado de la paz jurídica, cualquier ciudadano español podrá aprehender su persona si penetrase en el territorio nacional. Don Alfonso DE BOrßón será degradado de todas sus dignidades, derechos y títulos, que no podrá ostentar legalmente ni dentro ni fuera de España, de los cuales el pueblo español, por boca de sus representantes elegidos para votar las nuevas normas del Estado Español le declara decaído, sin que pueda reivindicarlos jamás ni para él ni para sus sucesores. De todos los bienes, derechos y acciones de su propiedad que se encuentren en el territorio nacional, se incautará, en su beneficio el Estado, que dispondrá el uso conveniente que deba darles". La nación de ciudadanos se ve postergada por el patriotismo de la memoria monárquica. Además si alguien quiere entretenerse puede leer la defensa de los mejores derechos dinásticos de la rama carlista en Quien puede ser el príncipe de sangre real que encarne el 18 de julio y el movimiento nacional, Madrid, 1964, y el libro de Fernando Polo, ¿Quién es el Rey?, Sevilla, 1967.. A la vista de la designación sucesoria, parece que el Dictador eligió quien podía encarnar "el 18 de julio y el movimiento nacional". Como consecuencia de la expulsión de Carlos Hugo de Borbón PARMA, formuló una pregunta al Gobierno el Procurador Don José Angel Zubiaur Alegre, quien con el tiempo llegaría a ser Presidente de Navarra, por la UPN, y en el que se relataba todo el pleito dinástico. Veáse Boletín Oficial de las Cortes Españolas núm. 1044, día 27 de febrero de 1969. 
pretendiendo los constitucionalistas sustituir o suplir ese hecho histórico -que no memoria como recuerda Paul Ricouer- el origen de la legitimidad con la legitimidad en el ejercicio constitucional. ${ }^{67}$ La posición institucional de la Corona, en expresión de Herrero de Miñón, es un prius, que deviene en un plus constitucional. El Rey sanciona, pero no jura la Magna Carta, sin que, como en las antiguas costumbres forales, jurare so arbol de Guernica, observar y respetar los fueros de los vizcaínos. ${ }^{68}$

Fiel a tradiciones históricas el poder constituyente, le considera un "princeps legibus solutus" (art. 56.3 en relación con los artículos 93,94 y 95.1), lo que empece o impide que la "nación de ciudadanos", suscriba y ratifique tratados sobre la jurisdicción penal internacional, a pesar de las enmiendas de los diputados nacionalistas vascos, anclados en la melancolía del Señor de Vizcaya, responsable conforme a fuero. ${ }^{69}$ Instituciones como la Regencia (art. 59), ${ }^{70}$ o las competencias regias sobre sanción y promulgación, completadas en el artículo 91 o sobre convocatoria del referendum (art. 92), ${ }^{71}$ sobre el nombramiento, dimisión de la Presidencia del Gobierno (art. 114, 115) y disolución del órgano representativo de la soberanía nacional (art. 115), nombramiento del presidente del legislador negativo (art. 169) son expresiones de riguroso historicismo en una Alta Magistratura del Estado, que se presentan, "á nos jours", como expresiones constitucionales propias de una Monarquía Parlamentaria, pero que no se compadecen con la regulación del Título

67. La lectura, entre otros, del libro de Rafael Borrás Betriu, El rey de los rojos. Don Juan de Borbón. Una figura tergiversada, Plaza \& Janés, Barcelona, 1996, es en ese sentido, reconfortante. No es de extrañar en la democracia alboraique que nos encontramos, que la publicación del libro de María Teresa de Borbón PARMa, Josep Carles Clemente y Joaquín Cubero, Don Javier, una vida al servicio de la libertad, La apasionante bistoria del bombre que osó enfrentarse a Franco y situó al Carlismo en la izquierda, Plaza \& Janés, Barcelona, 1997, publicado en la colección Así Fue. La Historia Rescatada, dirigida por el propio BORRÁs, fuere objeto de una peculiar crítica historiográfica por Miguel AYUSO, en las páginas del ABC del día 11 de noviembre de 1997 (p. 58), cuyo título era Una biografía falsa. A la vista de la biografía de Don Javier DE BORBÓN -dinastía legítima según el propio ordenamiento autónomo nobiliario- prisionero en el campo de exterminio de Dachau y de Don Juan DE BORBóN, prisionero en el campo de recreo de Estoril, no se puede ser, como diríamos ahora, equidistante.

68. Carlos Martínez Gorriarán, Casa, provincia, rey. Para una bistoria de la Cultura del Poder en el País Vasco, Alberdania, Irún, 1993, p. 363, transcribe un editorial de El Bascongado, periódico liberal publicado en Bilbao en 1813, citado por FERnÁNDEZ SEBASTIÁn, La génesis del fuerismo. Prensa e ideas politicas en la crisis del Antiguo Régimen (País Vasco, 1750-1840); Siglo XXI, Madrid, 1991, sobre el concepto de democracia igualitaria y constitución: «La opinión pública en el país bascongado es más favorable que en ningún otro a las nuevas instituciones. Ningún bascongado se asusta con el nombre dulce de la libertad. La ha gozado desde que existe (...) La soberanía nacional no es una novedad para los bascongados. Jamás se han creido patriminio de una familia particular. Ellos en sus juntas han elegido sus gefes supremos, principalmente los vizcaynos, y aunque les daban el título de Señores, no lo eran de hacer lo que quisiesen. Había entre ellos y el Señor pactos, o leyes constitucionales, cuya observancia debía jurar aquél, como el Rey deberá jurar en adelante la Constitución de la monarquía".

69. La defensa de la institución monárquica, como no podía ser de otra manera, dada su "historia concreta", en HERRERO DE MiÑón, "La posición institucional de la Corona", en S. MARTín-RETORTILLO (Dir). Estudios sobre la constitución española. Homenaje al Profesor Eduardo García de Enterría. Tomo III. Editorial Civitas, Madrid, 1991, pp. 1.921 y ss.

70. Veáse Amelia Pascual Medrano, La Regencia, Centro de Estudios Constitucionales, Madrid, 1998.

71. A este respecto, por todos, FANLO LORAS, "La expedición por el Rey de los Decretos acordados por el Consejo de Ministros (sus fórmulas promulgatorias tras la constitución de 1978)", y ARAGÓN REYEs, "Monarquía Parlamentaria y sanción de las leyes", en S. MARTín-Retortillo (Dir). Estudios ob. cit., pp. 1940 y ss., y 1961 y ss., respectivamente. 
V (De la Presidencia de la República), de la Constitución Española de 1931, más cercana al modelo de "nación de ciudadanos", en este caso, además, de trabajadores de todas las clases.

Si acudimos al Título VI (Del Poder Judicial), nos encontramos con que la justicia, aun cuando emana del pueblo, "se administra en nombre del Rey", quien nombra a propuesta del Consejo General del Poder Judicial al Presidente del Tribunal Supremo (art. 123.2) y al Fiscal General del Estado (art. 124.4) lo que hubiere hecho temblar incluso al Mirabeau DE Ortega, ${ }^{72}$ y qué decir tiene a Robespierre. ${ }^{73}$

En la organización del "corpus mysticum" del Estado, el historicismo brota a raudales en el Título ViII de la Constitución. No es preciso distinguir en la Geografía Política de la España Constitucional, expuesta con solidez por Jesús Burgueño, ${ }^{74}$ y en la interpretación orteguiana de S. Martín Retortillo, sobre la "rebelión de la provincia", el peso de la historia en la división provincial española, la aleja, en buena medida, del modelo imitado; el departamento francés concebido con criterios funcionales como circunscripción administrativa para la prestación de servicios. ${ }^{75}$

División provincial creada solapando las divisiones de jurisdicciones y señoríos, en 1833 por Javier de Burgos, y que mantiene enclaves de origen señorial, de los que el Condado de Treviño es blasón. ${ }^{76}$ División que constitucionaliza y sujeta a reserva de ley orgánica, el artículo 141 de la Constitución, de suerte que el poder constituyente, una vez más, se ha rendido ante la cartografía histórica, olvidando, por ejemplo, la visión antiprovincial del catalanismo democrático.

La organización autonómica se funda en el principio dispositivo del acceso a la autonomía de las "nacionalidades y regiones", admitiéndose la constitución en Comunidades autónomas a las provincias con entidad regional histórica (art. 143.1.), y estableciendo un procedimiento especial para aquellas comunidades "que en el

72. José Ortega y Gasset, Mirabeau y el Politico. Fondo de Cultura Económica, México, 2." Edición, 1993. Aparece publicado con el título Dos ensayos sobre Mirabeau, siendo el segundo un estudio de Jesús Reyes Heroles, Mirabeau o la política. Aun cuando Mirabeau era provenzal, OrTEGA Y GASSET se refiere al mismo y a su Famila como los Karazamov gascones.

73. La lectura del discurso pronunciado en la Convención el 3 de diciembre de 1972, recopilado bajo el título Sobre el proceso al rey, puede consultarse en la recopilación que Ediciones Península, en 1973, y con traducción de Jaume Fuster, publicó, Maximilean ROBESPIERRE, La revolución jacobina, pp. 74 y ss. Como España es una nación de naciones singular, nuestras cátedras universitarias están pobladas de jacobinos ilustrados en lo referente a la organización territorial del Estado o a la indivisibilidad de la patria, que devienen en jacobitas cuando del Título II (De la Corona), se trata.

74. Jesús Burgueño, Geografía Política de la España Constitucional. La división provincial, Centro de Estudios Constitucionales, Madrid, 1996.

75. Recopila sus opiniones "provincialistas" en un interesante libro, La provincia. Pasado, presente y fututo, Editorial Civitas. Madrid, 1991. Sobre la división provincial, GuArTa MarTorell. División Territorial y Descentralización IEAL, Madrid, 1975 y "Las Provincias españolas a partir de la Constitución del 78" en el Volumen Provincias y Diputaciones Provinciales, Granada, 1982.

76. No deja de ser extraño, o quizás mas normal de lo corriente, que la primera invocación de la territorialidad como principio histórico que se impone a la voluntad democrática de sus habitantes, fuere, precisamente la defensa encendida del mantenimiento de la división provincial en el caso de Treviño (Provincia de Burgos enclavada por mor de la historia en la provincia de Alava). Puede verse la manera de argumentar en los recursos de inconstitucionalidad sobre la incorporación de Treviño a la provincia exenta de Alava. La lectura de las alegaciones desde la provincia de Burgos y de la Junta de Castilla y León, presididas por un sedicente defensor de la "nación de ciudadanos", se tornan y rezuman el más espíritu tradicionalista provincial. 
pasado hubiesen plebiscitado afirmativamente proyectos de Estatutos". ${ }^{77}$ Casualmente las tres únicas comunidades que contaban en el "pasado" constitucional, formaciones políticas de carácter democrático y adscritas a fueros de pensamiento catalanista, vasquista o galleguista. ${ }^{78}$

El diccionario constitucional exige que la denominación de las Comunidades responda a su "identidad histórica" (art. 147.2 b). Y la Adicional Primera de la Constitución, consagra la claúsula de salvaguarda del derecho, al amparar y respetar los "derechos históricos de los territorios forales", completándose con la Disposición Derogatoria Segunda.

Claúsula de salvaguarda de los derechos históricos, cuya invocación ha permitido la aprobación, extra constitutione, y adornada de pactismo foral del Estatuto de Autonomía de Navarra, rebautizado históricamente, por la LO 13/1982 de 10 de Agosto de Reintegración y Amejoramiento del Régimen Foral de Navarra, cuya Adicional primera declara que la aceptación del régimen establecido en la presente Ley orgánica no implica renuncia a cualesquiera otros derechos originarios e históricos que pudieran corresponder a Navarra cuya incorporación al ordenamiento jurídico se llevará a cabo en la forma prevista en su artículo 71 , que declara -orden medieval navarro- que "dada la naturaleza del régimen foral el Amejoramiento es inmodificable unilateralmente", por la soberanía ex constitutione. Actualización así llamada del régimen foral navarro, en el Estatuto navarro, de dudosa constitucionalidad, como señaló Francisco Tomás y Valiente. ${ }^{79}$

Cláusula de salvaguarda de los derechos históricos que se refleja en Estatuto de Autonomía de la Vasconia occidental. El "pueblo vasco o Euskal Herría, como expresión de su nacionalidad, y para acceder a su autogobierno, se constituye en Comunidad Autónoma dentro del Estado Español", si bien, como señala la Adicional Estatutaria, "la aceptación el régimen de autonomía que se establece en el presente Estatuto no implica renuncia del Pueblo vasco a los derechos que como tal le hubieran corresponder en vitud de su historia, que podrá ser actualizado de acuerdo con lo que establezca el ordenamiento jurídico".

El Estatuto Vasco de Guernica, deposita los derechos históricos, en el sujeto estatuyente, en la soberanía popular, el Amejoramiento, empero, en la nación al modo foral, en el Cuerpo Político Provincial. ${ }^{80}$ Pero el carácter paccionado, en el caso navarro, no perturba la Constitución y reafirman determinada Política.

77. El pasado sustituye a la bistoria. No pudiéndose invocar el nombre (la República), se cita el pronombre. El pasado. Los Estatutos de Autonomía no podían ser otros que los aprobados en la II." República Española (el pasado), y en concreto, el de Galicia, Cataluña, y el caso especial del Estatuto de una Vasconia, casus belli, incompleta.

78. Son de enorme interés las reflexiones de Alfonso Rodríguez CastelaO, Sempre en Galiza, Editorial Galaxia, 6." Edición, Vigo, 1996, pp. 183 y ss.

79. "Informe sobre el Tribunal Constitucional Español", en Tribunales constitucionales europeos y autonomías territoriales, Centro de Estudios Constitucionales, Madrid 1985, p. 153, y pp. 156-158.

80. Conviene recordar que el Estatuto de Guernica fue promovido por el PSOE, UCD,EE, y PNV. Alianza Popular, hoy PP, votó en contra, lo cual no era, a la sazón de extrañar. Sin embargo el lenguaje bistoricista del Amejoramiento del Fuero, no supuso ningún problema para esta formación política. De su conversión al constitucionalismo liberal, podría predicarse aquello de iguárdenos Dios de la fe del Conversoj 


\section{EL ARPÓN DE LA NACIÓN DE CIUDADANOS. DE LA IMPOSIBILIDAD DE UN PATRIOTISMO CONSTITUCIONAL. OTRAS COMUNIDADES IMAGINADAS: DE LA AUTODETERMINACIÓN COMO PACTO FORAL}

Pueden rastrearse elementos de ambos en todos o en casi todos los estados europeos ${ }^{81}$ e incluso, como ha apuntado el maestro Isahia Berlín, en nuestro venerado filósofo de Köenigsberg. ${ }^{82}$ El segundo orden de críticas a la obra de Herrero de Miñón, descansa en el pronombre. Dado que reinvindicar el nacionalismo español socava la crítica al nacionalismo preocupante de Galeusca, al carecer de tradición democrática histórica que lo sustente como memoria colectiva, y dada la "amnesia estructural" derivada de la Constitución Española, el arpón empleado es el pronombre, el patriotismo constitucional.

Opción del patriotismo constitucional que se utiliza, habitualmente, desde los medios académicos, como crítica al nacionalismo vasco, sustentado, se dice, en un criterio etnicista de organización social. Las insuficiencias, geográficas, del patriotismo constitucional, aplicadas al poder constituyente y al poder constituido español, han sido puestas de manifiesto por autorizadas voces de la filosofia del derecho español. ${ }^{83}$

Hay una imposibilidad ontológica de aceptar un patriotismo constitucional, que nazca ex ovo de la Constitución Española de 1978, que pretenda descansar, y descanse, sobre el "memoricidio" de la resistencia constitucional, política y social del antifranquismo, como ha subrayado con tino, Lacasta Zabalza. ${ }^{84}$

Las tesis sustentadas al abrigo del precio de la transición, como ejercicio de olvido consciente o inconsciente, esté siendo sustituida imperceptiblemente, como si tal transición fuere un mero orden natural de las cosas derivada directamente

81. Franciso LetAmendia, Juego de espejos, ob. cit. pp. 21 y ss. Veáse Ronald Beiner, "Liberalismo, nacionalismo, ciudadanía: tres modelos de comunidad política", Revista Internacional de Filosofía Política (RIFP) núm. 10, UAM-UNED, pp. 5 y ss. Riva KASTORYANO, "La cuestión de la ciudadanía. Más allá de la sangre y la tierra", RIFP, núm. 11, 1998, pp. 48 y ss. REQuEJo Coll, "Pluralismo, democracia y federalismo. Una revisión de la ciudadanía democrática en estados plurinacionales", RIFP, núm. 7 , pp. 93 y ss.

82. Puede consultarse la aproximación al pensamiento de KANT, como fuente de cierto nacionalismo en Isaiah BERLIN, El sentido de la realidad. Sobre las ideas y su bistoria, Editorial Taurus, Madrid, pp. 331 y ss.

83. Vide, J.I. Lacasta-Zabalza, Tiempos dificiles para el patriotismo constitucional español, Cuadernos Electrónicos de Filosofía del Derecho. núm. 2-1999. Y "Los incultos avatares del nacionalismo español de nuestro tiempo". Revista EL Ebro, Revista Aragonesista de Pensamiento, núm.1, pp. 115 y ss. Son interesantes a este respecto las reflexiones de Albert CALSAMiglia, Cuestiones de lealtad. Limites del liberalismo: corrupción, nacionalismos y multiculturalismo, Paidos, Barcelona, 2000. Aparece publicada en la primera portada de un períodico bilbaíno correspondiente al 26 de septiembre de 2000 , el siguiente titular: "PSE, PP y UA impiden que se retire a Franco el título de Padre de Alava". La lectura de la noticia es suficientemente expresiva de la "amnesia estructural" de los partidos de la Restauración.

84. En este orden de cosas, el artículo de Manuel Pérez Ledesma, Memoria de la Guerra, olvido del franquismo, Letra Internacional, 67 , pp. 34 y ss. Parece que la cosa va, también, por barrios. Veáse, José FERnÁndez VEGA, "Dilemas de la memoria. Justicia y Política entre la renegación personal y la crisis de la historicidad", RIFP, Madrid, n. ${ }^{\circ} 14$, diciembre, 1999, pp. 47 y ss. Para el caso vasco, lo subraya Paloma Aguilar, "Memoria histórica y legados institucionales en los procesos de cambio político", en el mismo número de esta extraordinaria revista, p. 35 y notas correspondientes. 
del régimen dictatorial, rebautizado como régimen anterior. ${ }^{85}$ Las muestras y los gestos son evidentes. ${ }^{86}$

Retomando la tradición unitarista y enteca de la sociedad española, toda mención a la cuestión de "las Españas", se debate entre esos lugares oscuros creados institucionalmente o esa prolija precisión de críticas cánonicas ante las voces discrepantes. ${ }^{87}$ Podríamos reparar en un autor cuyo nombre revelaré una vez citado.

Pueden invocarse en esos "lugares oscuros" constitucionales, donde se refugia el Leviathan constitucional español. El texto es largo. Es incluso cita sobre cita: "En España ha habido un conflicto permanente entre el Estado y la nación, entendiendo por nación la clase que históricamente estaba destinada a tomar el Poder" tras una larga y aleccionadara de un escrito de Karl Marx sobre el orden constitucional español, 88 añade "la burguesía panespañola, heredera directa de las tradiciones de

85. Marc CARRILlo, artículo El País 28-XI-1997. Correspondería este orden natural de las cosas, a las reflexiones que José Manuel RocA, «El lienzo de Penélope. España y la desazón constituyente (18121978)", Los libros de la Catarata, Madrid, 1999, pp. 120 y ss. ha denominado, el discurso hegemónico sobre la Constitución de 1978, que se sustenta en que "el tránsito desde la dictadura franquista hasta el vigente régimen parlamentario es un proceso en sí mismo democrático - transición democrática que ha sido posible por la madurez cívica de que hizo gala el pueblo español, por el buen oficio de una clase política responsable, especialmente por las élites que condujeron al cambio -tanto los dirigentes de los dos grandes partidos de la izquierda como la élite reformista del propio régimen, encabezada por Adolfo Suárez- por el respeto al proceso mostrado por los llamados poderes fácticos, en particular por el Ejército, y por el respaldo dado por la Iglesia católica; por haber impulsado por un noble motor -la Corona-y haber sido patroneado hasta buen puerto por un excelente timonel -el Rey". Acompaña RocA una breve noticia de un periódico maoista el Beijing Informa 18, (Pekín, 7 de mayo de 1980, p. 13), cuya lectura y cotejo con la versión oficial española de la transición, provoca cierto sonrojo.

86. Recientemente a propuesta del actual Ministro de Interior, se ha concedido al Sr. ARCOCHA, la órden de mérito civil por su condición de víctima del terrorismo. Ciertamente el Sr. ARcocha, Jefe de la Comunión Tradicionalista de Vizcaya, y por tanto afín ideológico de la FAMILIA OrEJa, fue asesinado ignominiosamente por ETA. Sin embargo tomó parte en la operación de terrorismo de Estado denominada "Operación Reconquista" de Montejurra en el año 1976. Y a los dos asesinados en esta operación, Aniano JimÉnez SANTOS, y Ricardo García PELlejero, no se les ha reconocido la misma condición de víctimas del terrorismo. Véase, José Ángel Pérez-Nievas ABASCAL, "Víctimas y Víctimas", en Hika, núm. 114, pp. 89. No deja de ser sorprendente dado que en la "operación Reconquista", fue organizada desde los aparatos del Estado, como revela el Informe Negro sobre Montejurra de 1976, y fueron contratados directa e indirectamente por aquellos, entre otros, los servicios de Jean Pierre CHERID, miembro de la OAS, quien interviene en Montejurra de 1976, reaparece en el Batallón Vasco Español (UCD) y en los GAL (PSOE), secuestrando, entre otras ekintzak, a Segundo MAREY. Sobre la STS 2/1998 (Caso Marey), IGARTÚA SALAVERría, El caso Marey. Presunción de inocencia y votos particulares, Editorial Trotta, Madrid, 1999. Los gobiernos pasan la policía manent, parafraseando a BALZAC. O que se pretenda extender mecánicamente las acciones de resistencia de un monarcomano contemporáneo -moralmente aceptables o no- argumentadas y defendidas por la doctrina clásica española, bien que como excusa para derrocar príncipes protestantes, con la violencia organizada una vez instaurado el estado constitucional. La vindicación "histórica" del continuum de la violencia pretende hacer tabula rasa de la situación dictatorial en la que nace, y de la situación constitucional, en la que como residuo franquista, permanece.

87. El libro de LaCASTA ZaBalza, España uniforme. El pluralismo enteco y desmemoriado de la sociedad española y de su conciencia nacional e intelectual, Editorial Pamiela, Pamplona-Iruña, 1998, pone de manifiesto la escasa tradición democrática española, y como, con ese endeble y enteco pluralismo español, todo aquello que perturbe, democráticamente, la quietud estatal, se convierte en el nuevo "enemigo interior".

88. A la vista del artículo de Gregorio PeCEs BARBA, "Los Caprichos de los nacionalistas vascos", publicados en el periódico El País del 21 de septiembre de 2000, se hace más exacta la prognosis del filósofo de Treveris: "(...) Pero a pesar de su despotismo, el Gobierno no prohibía a determinadas provincias el regirse por leyes y costumbre distintas, emplear banderas de diversos colores y diversos 
opresión nacional del Estado monárquico, no está ni remotamente, dispuesta a tolerar una separación de Cataluña o Vasconia para formar luego la unidad ibérica sobre bases más seguras, sobre báses más firmes" y mientras que "el Estado no sea completamente destruido mediante una revolución victoriosa no habrá posibilidad de que Cataluña, Vasconia y Galicia, etcétera, disfruten de la libertad que como naciones les corresponde. El estado semifeudal luchará contra Cataluña de igual modo que en otros tiempos quiso impedir la liberación de los Países Bajos, Portugal, América, Filipinas y Cuba". E incluso la "aprobación por las Cortes del Estatuto de Cataluña no solucionará la cuestión nacional. El problema es mucho más hondo. El Estatuto no será más que una carta autonómica que confiere a Cataluña una delegación de Poder - pero no el Poder- en cuestiones administrativas, secundarias. Cataluña no recobra su personalidad nacional. Queda sujeta a la voluntad de la burguesía panespañola".

Las propuestas de las dos formaciones políticas mayoritarias (entonces CEDA y PSOE, hogaño AP-PP y PSOE), "la gran burguesía y la socialdemocracia. Ambas se oponen completamente a todo intento de descentralización. Que el Poder sea ejercido por la una o por la otra es lo mismo desde el punto de vista nacional. Las dos encarnan la tradición absorbente, imperialistas del viejo Estado. La cuestión nacional subsistirá igualmente".

No ha sido preciso adaptar el lenguaje del texto. No se trata el autor de un reaccionario nacionalista de base étnica, como identifica con proliferación de detalles, algún antiguo partidario de la "construcción nacional y del derecho de autodeterminación de las nacionalidades ibéricas", devenido, hogaño, en crítico habitual del nacionalismo democrático vasco. ${ }^{89}$

El texto corresponde a un pensador y hombre de acción revolucionario, de izquierdas, y antiestalinista "avant la lettre", formado en la tradición española. Es un texto escrito entre octubre y diciembre de 1931, en pleno período de esperanzas perdidas, llamado el "pasado" por la Transitoria de la Constitución Española de 1978. Es uno de los textos de Joaquín Maurín, recopilado con el nombre de La revolución española. De la monarquía absoluta a la revolución socialista..$^{90}$

sistemas de tributación. El despotismo oriental ataca la autonomía municipal sólo cuando ésta se halla en oposición con sus intereses directos y tiene la tendencia a permitir la existencia de las instituciones locales si le relevan de la obligación de hacer algo por sí mismo y le libran de los esfuerzos que exige una administración establecida según un plan y un sistema".

89. Pueden compararse diversos escritos de Antonio Elorza de manera sinóptica. Tómese Comunismo y cuestión nacional en Cataluña y Euskadi (1930-36): un análisis comparativo. Saioak, Año 1, 1977, y La modernización política en España. Endymion, Madrid, 1990. Hay más textos y palimpseptos cotejables. La memoria de las cosas es un amplio almacén.

90. Utilizo la edición casi inencontrable de la editorial Anagrama, Barcelona, 1977, correspondiendo las citas a las páginas 118 y ss. Pueden leerse, los artículos recopilados escritos en castellano y en catalán, de Andreu Nin, Por la unificación marxista. Castellote Editor, Madrid, 1978. Se recoge, entre otros, el artículo publicado en el número 12, de Comunismo, en mayo de 1932, con el título Consideraciones sobre el problema de las nacionalidades, concluye: "la cuestión catalana no es más que un aspecto de la revolución democrática en general. Esta revolución ha sido escamoteada, y como consecuencia, se prepara asimismo el escamoteo de la única solución posible que se pueda dar al problema catalán: el derecho indiscutible de Cataluña a disponer de sí misma, incluso a separarse de España si ésta es su voluntad». Sobre su concepción catalanista y revolucionaria, veánse los trabajos reopilador por con el título Andreu Nin i el socialisme, Universidad de Barcelona, 1998. 
Disipa otra de las prolijas y diminutas ferocidades de la doxa canonica, que argüye y desvela que en las vindicaciones vasquistas no hay otra base que un mero concepto de nación de base étnica, de carácter reaccionario y antidemocrático.

Paradójicamente la crítica a los nacionalismos periféricos, descansa en defensores de los principios liberales de corte francés o anglosajón. ${ }^{91} \mathrm{E}$ incluso se invoca como modelo de construcción nacional, el ejemplo francés - nación de ciudadanoscomo Carta de Mareas de mero cabotaje cuyas rutas han de imitarse. La cuestión estriba en pensar que dicho modelo de nación de ciudadanos, es sencillamente falso y mitológico.

Apunta Michel Freeman, cómo «el surgimiento del nacionalismo en la revolución francesa nos muestra cuan íntimamente relacionadas están estas dos formas de nacionalismo, y ayuda a explicar porque el amable nacionalista Dr. Jekyll se transforma empíricamente tan a menudo en el detestable nacionalista $\mathrm{Mr}$ Hyde. El concepto revolucionario francés de ciudadanía nacional era excluyente (a los pobres, mujeres y minorías étnicas o se les negaba o se les concedía de mala gana la ciudadanía) tiránico (por ejemplo para con los hablantes de lengua no francesa) e imperialista". ${ }^{92}$

Alguno de esos lugares oscuros del constitucionalismo español, es, como hemos señalado, la Corona, o la forma de Estado. La cuestión del soberano o de la autodeterminación política, devienen en realidades constitucionales intangibles e inmutables. El Leviathan se convierte en la única realidad histórica, realmente intangible. Las voces de los antepasados, revestidas de lenguaje garantista de los derechos individuales, sirven, para mantener el satus quo del Estado nacional realmente existente, ${ }^{93}$

Otra vOz catalanista y revolucionaria en Jordi ARQUER, "El problema de las nacionalidades ibéricas, y El comunismo y la cuestión nacional y colonial”; sobre la cuestión vasca José Luis ARENILLAs, "El problema nacional de Euskadi", en la recopilación de Victor ALBA, La Nueva Era. Antología de una revista revolucionaria. 1930-1936, Ediciones Júcar, Madrid, 1976

91. Pierre-André TAGUiEFF, El nacionalismo de los nacionalistas. Un problema para la historia de las ideas políticas en Francia", en Gil Delannor y Pierre André TAGuIEFF, Teoría del nacionalismo, Editorial Paidos, Barcelona, 1993, p. 74, subraya como la crítica del pensamiento nacionalista, puede definirse por dos tipos de referencias: a) aquella cuya referencia es una transcedencia de orden religioso, "la catolicidad, supranacional y metanacionalista del cristianismo, de ahí la crítica católica a cierto nacionalismo como concepción pagana que interpone un elemento de distorsion de la universalidad católica, b) aquella cuya referencia es la "variante humanitaria de la gnosis del progreso necesario e indefinido, determinante del bien común como un bien cosmopolita y el progreso como realización del género humano."

92. Citado por John SCWARZMANTEL, "Nacionalismo y democracia", Revista Internacional de Filosofía Política, núm. 3 UAM-UNED, p. 29. Se hace eco Toscano MÉndez, ¿Democracia, ob. cit., p. 109, al señalar "cómo basta recordar la forma en que la ideología republicana francesa, paradigma de la nación cívica, ha tratado a sus minorías culturales y lingüísticas, con procedimientos de asimilación que hoy juzgaríamos más que dudosos desde un punto de vista liberal".

93. JAUREgut Bererciartua, Contra el Estado-Nación. En torno al becho y la cuestión nacional" Siglo XXI, Madrid, 1986, y La nación y el estado nacional en el umbral del nuevo siglo" en C.E.C., Madrid, 1990, y en "La autodeterminación en la perspectiva del siglo XXI" en la R.V.A.P., núm. 41, pp. 819 y ss. Sobre el "ius seccesionis" y el principio de autodeterminación en la Constitución, RuIPEREz AlAmILlo, Constitución y autodeterminación, Ed.Tecnos, pp. 55 y ss. en el que se defiende la tesis que los españoles nos "autodeterminamos" al aprobar el texto constitucional. Sobre la cuestión del derecho de autoderminación, desde el punto de vista del mos gallico de la constitución de 1978, Rodríguez-Zapata Pérez, "Sobre el derecho de autodeterminación y su compatiblidad con la constitución", Teoría y Realidad constitucional, núm. 3. 1999, pp. 103 y ss. Una clave mejor temperada en Javier CorcuerA ATIENZA, "Nacionalismo, autodeterminación y derecho", Cuadernos de Alzate, núm. 21, pp. 5 y ss. En la misma revista puede leerse el trabajo de Edurne URIARTE, "Democracia y falacias de la autodeterminación". pp. 43 que 
dado que cualquier desbordamiento de la acequia de la restauración, deviene en fuero de pensamiento políticamente incorrecto. ${ }^{94}$

E incluso, como en el caso las tesis de Herrero de Miñón, cuando la Adicional Primera de la Constitución se propone, en una lectura abierta e integradora, ${ }^{95}$ no sólo como claúsula de salvaguardia de los "derechos históricos", sino como convención constitucional (Dicey) ${ }^{96}$ o compromiso o equilibrio (Ausgleich), desde los elementos de pactismo que contienen ambos estatutos de la Vasconia peninsular que permiten "articular una relación de cosoberanía", ranía compuesta". ${ }^{98}$

reitera los lugares comunes y prejuicios, sobre las tesis soberanistas y su identificación con un atentado a la democracia, la legitimación de ETA, y argumentos de ese tenor. Califica de "error" las propuestas de autodeterminación formuladas por cierta izquierda (PCE y también el PSOE), contaminada, al parecer. De la ignorancia sobre otras izquierdas (republicanas federales, libertarias, POUM, etc.) ex silente cordis, explica su impartición de doxas, en las que ciertamente sí que sigue tradiciones totalitarias de cierta izquierda. Declara sinónimos el federalismo y el Estado autonómico, lo cual no es excesivamente preciso. Una interpretación contraria al derecho de autodeterminación, en Juan José SolozABal, Autodeterminación y Constitución, pp. 43 y ss. Al parecer se ha asentado esta interpretación en la doctrina española, que olvida, por ejemplo, no sólo las circunstancias políticas del momento, sino que la elección había de optar entre el Antiguo régimen, y el nuevo, incluyendo en este último cuestiones tan dispares como el Título I, el Título VIII, o el Título II. ¿Acaso se autodeterminó la forma de gobierno? Desde una crítica a la realidad constitucional existente, los trabajos recopilados bajo el título Propuestas para un nuevo escenario. Democracia, Cultura y cohesión social en Euskal Herria, editado por el Instituto Manu RoblesArangiz, Bilbao, 1999. Singularmente la denominada Area de Ciencia Política, coordinada por Francisco LETAMENDIA BELZUNCE, La autodeterminación en Euskal Herria: actores colectivos, territorialidad y cambio político, pp. 31 y ss. y el Ârea jurídico-Institucional, coordinado por Iñaki LASAGABASTER HERARTE e Iñigo LAZKano BRotons, Derecho política e bistoria en la Autodeterminación de Euskal Heria, pp. 174 y ss.

94. Las notas de LACASTA ZABALZA, El pensamiento jurídico correcto. Sobre los límites implícitos para la libertad de critica del sistema estatal y constitucional español. Príncipe de Viana, Suplemento de Ciencias Sociales, Año XVII, núm. 6, 1997, pp. 43 y ss. sobre el origen ideológico del derecho de autodeterminación en la izquierda española, frente a las tesis nacionalistas del "foralismo pactista" o de la "independencia", más caras a las formaciones nacionalistas; y que figuraba, sin ir más lejos, en las propuestas del PCE y del PSOE. Sobre la mudanza de este último, las notas apuntadas por Mikel ALDASORO JAUREGUI, "PSOE 1975-1978 eta sujeto politikoaren aitorpena estatuaren egituraketa konstituzionalean", en Revista Gerónimo de Uztariz, Pamplona-Iruñea, 1999, núm. 14-15, pp. 123 y ss.

95. Sobre las categorías de una Constitución abierta, el propio HERRERO DE MIÑón, vuelve en "La dinámica de una Constitución abierta", en XX años después. La Constitución cara al siglo XXI, Madrid, Taurus, 1998. Sobre la constitución abierta LUCAS VERDÚ, en "Historicismo y positivismo ante la conceptualización de los derechos históricos vascos" en el volumen, Jornadas de estudios sobre la actualización de los Derechos Históricos Vascos UPV, 1986, Bilbao, pp.254 y ss.; en "Los derechos históricos como constitución sustancial del Pueblo Vascon, en el volumen Los derechos históricos vascos, IVAP, Oñati, 1988. La expresión de la paligenesia en La Constitución en la encrucijada (Paligenesia iuris politici), que corresponde a su Discurso de recepción en la Real Academia de Ciencias Morales y Políticas, Madrid, 1994. Uno de los síntomas del carácter abierto de la Constitución española, como consecuencia de la Adicional Primera, en La constitución abierta y sus enemigos. Universidad Complutense, 1993, pp. 42 y ss.

96. HeRRERO DE MiÑón, Derechos históricos, ob. cit., p. 319.

97. HERRERo DE MiÑón, Autodeterminación y derechos históricos, ob. cit., pp. 220-221.

98. TosCANo MÉNDEZ, Democracia de los ciudadanos, ob. cit., p. 114., recuerda que "la soberanía compuesta" fue la gran originalidad del federalismo americano, "a contracorriente del pensamiento político de la época". La república compuesta, defendida no era "ni una confederación de cuerpö políticos que retienen su soberanía ni un Estado unitario y soberano", se trata, y en eso radica la "novedad subrayada de Madison a Tocqueville" de una asociación de Estados soberanos en una federación también soberana". La legitimidad de dicha composición, prosigue Toscano, "descansa sobre un doble contrato, sobre un complejo equilibrio entre We, the people y We, the states, por seguir el ejemplo americano." Y concluye, ese es "el camino señalado en el artículo $2 .^{\circ}$ de la Constitución española que 
La Constitución abierta, como señala el autor, supone "una soberanía, fruto de la integración de una realidad policrática y una interpretación jurídica propia del derecho dúctil".99 Por ello, sostiene Herrero de Miñón, la actualización constitucional del concepto de "pacto" tan caro a la doctrina jurídica, pública y privada, y política fuerista, ha de transformarse en un "reconocimiento formal de la cosoberanía", para el que no hay, "dificultad" constitucional alguna, sobre la base de esa interpretación abierta de la Adicional de la Magna Carta. ${ }^{100}$ El problema sería, a la postre, "señalar los cauces mediante los cuales desarrollar por vía de pacto el potencial de los derechos históricos hasta convertirlos en instrumentos de autodeterminación". ${ }^{101}$

A juicio del autor, la autodeterminación no supone, necesariamente, la independencia de Vasconia, sino la introducción en el orden constitucional, de un viejo principio liberal que exige el "consentimiento de los gobernados como única fuente de legitimidad del gobierno", y que responde, además, a la tradición pactista.

En el caso de Herrero de Miñón, su pactismo descansa en la consideración de los cuerpos politicos provinciales forales, como fragmentos de Estado como un prius, que el propio texto constitucional consagra en la Adicional Primera. ${ }^{102}$

habla de la nación española al tiempo que reconoce la existencia de nacionalidades ( y regiones), pues afirma que la soberanía corresponde al conjunto de los ciudadanos españoles como que existen comunidades con una personalidad política y cultural diferenciada, con derecho a la autonomía y derechos históricos".

99. Herrero de MrÑón, Autodeterminación, ob. cit., p. 220. A mi juicio en este artículo, se refleja la impregnación de cierta cultura jurídica soberanista, que le permite ir un paso más allá -y bienvenido sea- de las tesis mantenidas en Ideas de los derechos bistóricos y en Derechos Históricos y Constitución, en los que las tesis de la soberanía o cosoberanía aparecían más veladas, o se invocaba el carácter paccionado del Estatuto de Guernica o del Amejoramiento Navarro, pero no como reflejo de dos soberanías preexistentes, sino de una soberanía conforme a fuero.

100. Escribía José Luis Arenillas, médico vasco, y miembro del POUM, quien fuera Jefe de Sanidad del Ejército de Euskadi durante la guerra civil, hecho prisionero en Santoña en agosto de 1937, y ejecutado a garrote vil en Bilbao, en marzo de 1938, en la revista La Nueva Era, en el mes de enero de 1936, lo siguiente: “los primeros gobernantes de la República prosiguieron la tradición de la monarquía absoluta sobre el problema de las nacionalidades. Reconocieron como aquélla, sobre el papel, la existencia de las particularidades nacionales y prometieron lo que de grado nunca habían de conceder (...) Los municipios con mayoría nacionalista proclamaron la República vasca vinculada en federación con la República Española, y reclamaron la derogación de la Ley de 1839 y el retorno a las viejas instituciones del país Vasco" Y citando a José Antonio Aguirre, añade, "Esta idea acordada el día 14 en el Ayuntamiento de Guecho fue aprobada el día 15 por numerosos municipios de Vizcaya, y el día 16 de convocaba a Juntas Generales en Guernica para el día 17 de abril de 1931", Bajo el árbol santo -prosigue ARENILLAS- fueron invitados a una Asamblea todos los Municipios Vascos con el fin de restaurar las Juntas Generales Históricas que en otros tiempos expresaban la soberanía de Euzkadi. No obstante las promesas hechas con anterioridad por los prohombres republicanos y socialistas -entre los que descuellan las declaraciones de Prieto, que prometió una "autonomía como nunca los vascos pudieron soñar- las autoridades que representaban en el País al Gobierno Provisional de la República suspendieron el acto y dispusieron la movilización de tropas, truncando, de esta suerte una vez más, el anhelo vasco de libertad. Con tal proceder, dieron lugar a que se exacerbara la emoción nacional de los vascos, cuyo movimiento democrático fue sofocado a pretexto de un ataque al nuevo régimen, y dejaron pendiente de solución uno de los problemas claves de la revolución democrático burguesa".

101. Herrero de Mĩ̃ón, Autodeterminación, ob. cit., p. 221.

102. HeRrero de Miñón, Idea de los derechos Históricos, ob.cit., pp. 127-128. También en su comentario al libro de Tomás Ramón FERNÁNDEZ, "Los Derechos históricos de los territorios forales", publicado en el n. 14 de la REDC, pp. 345-351, donde retoma alguna de sus propuestas descritas en el "Prólogo" a la obra de Jellinek, Fragmentos de Estado, Madrid, Civitas, 1978. Entre otras cuestiones señala: 
Llega a señalar, que: "Lo que tal pacto de unión ha de alumbrar, en último término es una concepción paccionada de las relaciones entre Cataluña o Euskadi y el Estado, como corresponde a entidades originariamente diferenciadas y no subordinadas una a otra, sino relacionadas para utilizar un término venerable equae principale. Pero esto supone, por una parte reconocer la soberanía originaria de las diferentes naciones catalana y vasca, su plena competencia sobre lo que le es propio y por otra parte, y consecuentemente la inderogabilidad singular de su situación constitucional que no puede ser afectada ni sólo por el Estado ni decidida sólo por ellas mismas. El pacto es, de esta manera, fruto de la autodeterminación histórica, pero, a la vez, su vigencia y su interpretación exceden de una sola de las partes que lo celebran. Pero más importante que la inderogabilidad singular del pacto es la voluntad de seguir pactando todos los días. La versión político-jurídica del querer vivir distintos y juntos a la vez". ${ }^{103}$

Esta primera intepretación del pacto entre los fragmentos de Estado y el propio Estado, constituye el Ausgleich constitucional que permite, desde una lectura útil, la Disposición Adicional Primera de la Constitución de 1978.

No olvidemos, además, las propias convicciones monárquicas de Herrero de Miñón, ya expresadas en libros anteriores. De hecho hay un intento hercúleo de salvaguardar la institución monárquica, a cuya legitimidad de origen y de ejercicio nos hemos referido supra, convirtiéndola en la piedra angular de la propuesta.

En los primeros trabajos, esta contribución rescataba la vieja, pero útil, teoría, de la unión principal, tan cara a los fueristas navarros, y cabía rastraer influencias no solo de Jellinek, sino del Otto Bauer de Die Nationalitätenfrage und die Sozialdemokratie que glosa el estado federativo (Bundestaat) de la Monarquía Austrohúngara, de suerte que la idea de un agregado de naciones (Nationalitätenbundestaat), se convierte en un instrumento de la Corona Española (Werkzeug der Krone).

Las tesis que se reelaboran en Derechos Históricos y Constitución y en su artículo Autodeterminación y derechos Históricos, aun cuando se entroncan en esta intepretación del principio monárquico, se han "normativizado", o si se prefiere, de unión personal, se transubstancia en unión de ordenamientos jurídicos. Si la soberanía es decisión -apunta el autor-y quien condiciona la decisión

"es fácilmente comprensible que si algún freno seguro hay a la tentación separatista es precisamente esta versión interprovincial de la autonomía" (p. 347), calificando de "fragmentos de estado" a los territorios históricos, concluye: «A mi juicio el futuro autonómico español pasa por transformar un fragmento de Estado las grandes entidades históricopolíticas de la periferia española y disolver en mancomunidades de poderosas provincias la mayor parte del territorio, no cargada de hechos diferenciales. La Constitución, inteligentemente interpretada, da pie a ello. Pero simultáneamente el Fragmento de Estado me parece que puede servir para explicar y garantizar la posición de los territorios históricos como pieza clave de Euskadi, Fragmento de Estado a su vez. El resultado sería un fragmento de fragmentos, de los que la experiencia comparada ofrece ejemplos." Recupera la figura de los fragmentos de Estado, en "Los Territorios Históricos como fragmentos de Estado" en el Volumen Los Derechos históricos vascos, ob.cit. pp. 263 y ss. Esta tesis se extiende en su libro Idea de los derechos históricos.. ob.cit. pp. 105 y ss. Recopilada en Derechos históricos, ob. cit. pp. 159 y ss.

103. Puede apreciarse una evolución interesante de su pensamiento en su artículo "Nacionalismos y Estado plurinacional en España", en Política Exterior núm.51, 1996 , pp. 7 y ss. 
codecide, la codecisión implica cosoberanía y la coseboranía no es otra cosa que codecisión. ${ }^{104}$

Ciertamente las tesis de Herrero de Miñón sorprenden, porque están pensadas y repensadas y hunden sus raíces en la cultura jurídica española. Se ha hablado del decisionismo castellano. No es preciso traer a colación ese concepto tan caro al decisionismo normativo castellano, que es la democracia de la pena de muerte, que describe Zagrebelsky, que ha convertido los procesos democráticos y electorales en una mera legitimación del diktak del Leviathan constitucional. ${ }^{105}$

Reflejo de esa cultura del "decisionismo constitucional" era Cánovas del Castillo, para quien la nación española es "obra de Dios", y en su conocido Discurso en réplica a los diputados fueristas navarros, manifestaba que "un hecho de fuerza es lo que viene a constituir el derecho, porque cuando la fuerza causa estado, la fuerza es el derecho".

Ejemplo de una profundamente cultura liberal del pacto, Hermilio DE Olóriz, describía en 1894 la falta de respeto al derecho que caracterizaba al Gobierno español, señalando, "Nadie ignoraba y todos reconocen que para los gobiernos españoles, presídalos Cánovas o Sagasta, no hay derecho merecedor de respeto si poderosa fuerza no lo mantiene". ${ }^{106}$ Este juicio de Oloriz, educado en el liberalismo jurídico del sexenio revolucionario, es aplicable, en esta nueva restauración en la que se desenvuelve la vida politica española. ${ }^{107}$

Liberalismo español (decisionismo castellano diría Lalinde Abadía), escasamente acostumbrado a la cultura del pacto (paramiento fuero vienze), de la observancia de los compromisos, y del orden jurídico creador del Estado, como cesión de soberanía individual o colectiva, y más cercano a la consolidación de la fuerza como derecho, y a la aceptación de los procesos jurídicos constitucionales y electorales no como actos constitutivos del poder público y de la cesión, revocable, parcial o total de soberanía, sino como reflejo de una cultura del absolutismo monárquico borbónico, de legitimación del poder preestablecido.No iba a ser España diferente. ${ }^{108}$

Frente a ese cultura "liberal" española escasamente respetuosa con el derecho, y con el derecho de los demás, hay otros árboles de variedades distintas y plurales, llenos de espesura que dan cobijo y frescura. No es menester invocar a $\mathrm{Pi}$ i Margall, a Almirall, a Carretero, a Torrente, a Castelao, ni acudir a lecturas sobre el multiculturalismo de la constitución algonquina. Basta releer sin prejuicios la

104. Herrero de Miñón, Derechos, ob. cit., p. 317, y Autodeterminación, ob. cit., p. 220.

105. Gustavo Zagrebelsky, La crucifixión y la democracia, Ariel, 1996, pp. 109 y ss. y passim. Son de interés las reflexiones de Dolf STERnBERger, Dominación y acuerdo, Editorial Gedisa, Barcelona, 1992, pp. 129 y ss.

106. Hermilio de OlORIz, La cuestión foral. Reseña de los principales acontencimientos ocurridos desde mayo de 1893 a julio de 1894. Reedición del libro de Pamplona de 1894, y reeditado por Txalaparta, Tafalla, noviembre de 1894.

107. Vease a ese respecto LACASTA ZABALZA, España uniforme, ob. cit. passim.

108. Ese fenómeno fue observado con su agudeza y lucidez por Toceueville, al analizar los "lugares oscuros" del régimen revolucionario, y la pervivencia de los conceptos del "arjé" político más propios del Estado absolutista, y que estallan en el formalismo de la Constitución y que dan paso a la restauración Napoleónica, en El Antiguo régimen y la revolución (1856). 
historia y las tesis de los juristas y tratadistas fueristas de las dos Vasconias. Y esto es lo que hace Herrero de Miñón, desde una posición políticamente conservado$\mathrm{ra}$, no cae en el conservadurismo de sus críticos - de facto cualquiera que sea la progresía nominal de sus cultivadores-. ${ }^{109}$

\section{HERRERO DE MIÑÓN Y LA ESPAÑA GRANDE. LA DUCTILIDAD Y UTILIDAD DE LA CONSTITUCIÓN. LA ADICIONAL PRIMERA DE LA CONSTITUCIÓN COMO FUENTE DE UN "AUSGLEICH" FORAL}

Empero, la propuesta de Herrero de Miñón, pretende resolver el arte de marear y aparejar Vasconia en y con España Grande. A su juicio, el Estado constitucional español no puede descansar única y exclusivamente en un mero ordenamiento jurídico, en cuyo vértice se encuentra la Constitución Española de 1978 como fuente de validez de las demás normas inferiores y criterio último de organización de la poliarquía limitada de los poderes públicos estatales y autonómi$\cos$, incorporado por la vía del bloque de la constitucionalidad. ${ }^{110}$

No existe, siguiendo la huella de Smend, una garantía externa de las reglas del juego constitucional, "no se remite a su poder efectivo, sino a la aquiescencia libre y renovada de sus miembros". ${ }^{111}$

¿Qué ocurre en lo relativo a la "aquiescencia libre y renovada de sus miebros"? Nos encontramos con una significativa Cofradía de mareantes (Corpus politicum) la vasca, que no se identifica ni reconoce en el titular de la soberanía nacional del artículo $2 .^{\circ}$ de la Constitución, en cuanto que se considera comunidad originaria o primigenia, distinta del soberano pueblo español. ${ }^{112}$

Este es un dato de hecho incuestionado, sin necesidad de acudir a la recurrente democracia de sondeos criticada por Zagrebelsky. ${ }^{113} \mathrm{Y}$ no es nuevo.

109. HeRrero de MiNón, Derechos y constitución, ob. cit., p. 318.

110. Es de enorme interés el estudio preliminar de GARCía AMADO a la obra de Hans KELSEN, El Estado como integración. Una controversia de principio, Editorial Tecnos, Madrid, 1997, pp. IX-XXI, en el que se reflejan las discrepancias de aquél con las tesis del Estado como integración de SMEND.

111. Recoge Stephen Holmes, ob. cit., pp. 80 y ss., la crítica de ScHMITT, que subraya como los principios del gobierno de la mayoría y de la igualdad sólo pueden funcionar en la práctica en los "confines de fronteras territoriales legítimas, pese a que tales principios son por completo incapaces de crear o justificar tales fronteras". ¿Y qué ocurre cuando se discuten las fronteras del demos? En esta ocasión y sobre los balleneros de Land un Meer: Eine weltgeschichtlicheBetrachtung, que conquistan los mares, pp. 80 y ss. Sobre estas cuestiones, EstÉvez Araujo, La crisis del Estado de Derecho Liberal, Aries Derecho, Barcelona, 1988, passim. Una crítica de la interpretación en RuIz Miguel, en su "Estudio Preliminar" de la obra de Carl ScHMIT, Catolicismo y forma politica, Editorial Tecnos, Madrid, 2000.

112. Las razones históricas que avalen o no dicha percepción, la falsificación o acomodación de la historia desde una visión nacionalista, en un reflejo, por cierto de la acomodación de la historia española a un proyecto nacional determinado, no empecen para constatar que de integración de ciudadanos, de reconocimiento en la "comunidad imaginada", se trata, ¿serán los ciudadanos vascos que no se consideran ni reconocen como españoles desde la teoría de los derechos cívicos obligatoriamente españoles con arreglo a la Nación bistórica? La paradoja está servida.

113. A los sondeos, no muy actualizados, recurre Alfred STEPAN, "Las modernas democracias multinacionales: superando un oxímoron de Gellner", en John A. Hall (Ed.) Estado y Nación, ob. cit., p. 308, siguiendo los trabajos de Linz. Problems of Democratic Transition and Consolidation. 
Lo puso de manifiesto $\mathrm{Pi}$ i Margall, al preguntarse ¿por qué criterio pertenecen los vascos a España?, y, añade, como tras las guerras civiles -carlistas- "vencidos, se les ha arrebatado con los fueros la exención del servicio militar y de los tributos? ¿Son por eso más españoles? ¿Participan más de nuestras ideas y sentimientos?». Y concluye "a poco que se combine aquí los distintos criterios para la teoría de las nacionalidades, tengo para mí que se habrá de estar por la independencia de los vascos. ¿La consentiría España?114

Esta es, a mi juicio, la mar constitucional en la que Herrero de Miñón, ha de describir prescriptiva y normativamente la Carta de Navegación de este archipiélago foral. ¿Puede el interpréte limitarse a una mera glosa de la Constitución como norma jurídica?

Si se predica el carácter jurídico de la Constitución, se convendrá en determinar que la propia Disposición Adicional Primera es, también, una norma jurídica. Advertía Herman Heller, del consejo de Kelsen, "procura, al efectuar la exposición del derecho positivo de un estado, hacer desaparecer su personalidad y aún el concepto mismo de estado, y así podrás observar cuán facilmente marcha todo", por lo que concluía, es indudable que este estado-ficción no puede ser nuestro objeto de la soberanía. ${ }^{115}$ La demostración del derecho positivo de la Constitución Española, a juicio de Herrero de Miñón, introduce palos en la rueca de ese cuan facilmente marcha todo, y que olvida que la Constitución, no solo es mera mecánica jurídica, sino elemento de identificación cívica, de integración y lealtad ciudadana.

Prontamente subrayó su normatividad Bartolomé Clavero, al entender que la cláusula de salvaguarda de los derechos históricos, es también, una norma jurídica, frente aquellas opiniones doctrinales que reducían su valor a una proclama simbólica. ${ }^{116}$

114. Francisco PI I Margall, "Las nacionalidades", Cuadernos Para el Diálogo, Madrid, 1973, pp. $140-142$.

115. Hermann Heller, La Soberania, ob.cit., p. 146. La relectura de la conferencia de Hermann HeLler, pronunciada en 1925, con el título "Estado, nación y socialdemocracia, y Socialismo y nación" en Escritos Políticos, Alianza Universidad, Madrid, 1985, pp. 135 y ss. pueden ser en ese sentido de interés, sobre el despiste de cierta socialdemocracia ante el hecho nacional. En ese sentido, Las ideas politicas contemporáneas, colección Labor, Barcelona, 1930, pp. 118-149.

116. Óscar AlzAGA, Comentarios a la Constitución", Madrid, 1978, se limitaba a señalar la primera y más radical crítica a la misma por su innecesariedad y falta de encuadre en el sistema constitucional (p. 978); afirmando asimismo que su única justificación no era sino el "mostrar un gesto histórico de comprensión", advirtiendo, desde su peculiar concepción política, que la misma tenía a los ojos del nacionalismo vasco representado por el PNV-EAJ, la consideración de "fuente de derechos distinta a la soberanía nacional". Admonición hecha, vino a colegir que en puridad no se trata de "expresiones genuinamente técnico-jurídicas" que implicaran una fuerza de obligar. Similares términos emplea en los Comentarios a la Constitución, dirigidos por GARRIDO FAlla (1.' Edición, 1980), en este concreto punto EnTRENA CUESTA redactor de la glosa a la Disposición Adicional Primera, (pp. 175.155). Amen de dar cuenta del iter parlamentario de la Disposición Adicional Primera viene a coincidir sustancialmente con los postulados de Óscar AlZAGA, al calificarla de "fórmula que abriese los caminos para su ansiada pacificación"; añadiendo en este punto que aquélla habría de plasmarse en una "Ley paccionada" (p. 1.753). Resurge esta última idea en LEGAZ LACAMBRA, quien en el "Prólogo" a la obra de C. STARCK, El concepto de la Ley en la Constitución Alemana, IEP. Madrid; viene a aseverar cómo aquélla "abre la posibilidad a una forma de ley que sería la ley paccionada, a la que la Constitución no hace referencia expresa por que deja imprecisa la forma en que se actualizan en el marco de la Constitución y de los Estatutos de Autonomía" los derechos históricos de los territorios forales. LópEz Ronó, en 
Su dicción literal es conocida. ${ }^{117}$ ¿Qué hermenéutica constitucional puede emplearse para desentrañar no sólo quienes sean los "territorios forales", cuestión menor, sino qué sean los derechos históricos? ¿Y cómo interpretarla? Desarrollando y reelaborando sus tesis anteriores, resume el propio HERRERO DE MiÑón los tres conceptos fundamentales de la doctrina constitucional de los derechos históricos: el del cuerpo político, el del pacto y el de la integración. ${ }^{118}$

Ciertamente hay dos aplicaciones directas que han sido citadas:

a) En el caso de Navarra, la Adicional Primera ha servido para justificar la constitución de una comunidad autónoma, sin ajustarse al procedimiento constitucional del Título VIII de la Constitución Española de 1978. Cierto es que este uso historicista, paccionado, para la aprobación del Amejoramiento navarro, no ha generado ningún conflicto. Si el caso vasco es una cuestión de Estado, Navarra, o mejor dicho, su no integración con el resto de las provincias exentas, es una apuesta política decidida, como cordón sanitario que amortigüe veleidades nacionalistas. ${ }^{119}$

b) En el seno de la propia comunidad autónoma, critiqué el uso de los derechos históricos como vaciamiento del poder público nacional vasco, a favor de las instituciones provinciales, de tal suerte que la apelación foral socavaba el principio nacionalitario de Vasconia occidental. ${ }^{120}$ Los derechos históricos en el caso del Estatuto de Autonomía de Guernica, han servido como título específico de aquellas competencias que en su momento, denominé el bloque legendario que se hizo Constitución en los artículos 16 (Enseñanza), 17 (Policía) y 41 (Concierto) del Estatuto Vasco, en títulos competenciales especialmente sensibles para la ciudadanía vasca.

La identificación de ese Corpus políticum preexistente, titular de los derechos históricos, se resuelve dúctilmente, mediante la teoría de la novación.

"El orden de competencias establecido en la Constitución. Origen de los conflictos entre el Estado y las Comunidades Autónomas", aparecido en el Volumen II, de los Estudios sobre el Tribunal Constitucional, editados por el IEF. Madrid, 1981, p. 1.474. Sobre el concepto empleado, lo explica el propio autor, en "Filosofía del pactismo" en el volumen colectivo El pactismo en la Historia de.España, Madrid, 1980. En este sentido compromisario se expresa igualmente Gumersindo TrujiLlo en el volumen Constitución Española. Edición comentada, edición a cargo del Centro de Estudios Constitucionales, Madrid, 1979, p. 36.970. A su juicio la citada Adicional Primera, no tendría otro propósito ni otra consecuencia que la de "encontrar una vía razonable para afrontar el problema vasco".

117. "La Constitución ampara y respeta los derechos bistóricos de los territorios forales. La actualización general de dicho régimen foral se llevará a cabo, en su caso en el marco de la Constitución y de los Estatutos de Autonomía.

118. Herrero de MiÑón, Derechos, ob. cit., p. 320.

119. Una crítica del procedimiento de aprobación de la LORAFNA, en TOMÁs Y VALIENTE en "Informe del Tribunal Constitucional de España", en el volumen Tribunales Constitucionales Europeos y Autonomias Territoriales, en el CEC. Madrid, 1985, págs 156-157, quien señalaba "quizá pudiera especulativamente dudarse de la escrupulosa constitucionalidad del peculiar acceso de Navarra a su actual régimen autonómico". Otra suerte de críticas al proceso en LOPERENA RoTA, Aproximación, Ob.cit. pp. 105 y ss. Justifican la constitucionalidad del proceso, entre otros, en CosCulLuela MunTANER, "La Ley de Amejoramiento: Elaboración, naturaleza y principios" en el volumen "Derecho público foral...", ob.cit., pp. 267 y ss.

120. Carlos Coello Martín, La Disposición Adicional Primera de la Constitución y la organización autonómica vasca, Universidad de La Rioja, Logroño, 1997, que se subtitulaba, expresivamente, la "quiebra del modelo vasco", de organización territorial interno de la Comunidad Autónoma Vasca. Algunas de las ideas apuntadas las recupera CORCUERA ATIENZA, "Derechos históricos y nacionalismo", en Foralismo, Derechos Históricos y democracia, Madrid, 1998, pp. 212-213. 
Dada la inexistencia de un poder público común en la Vasconia peninsular, a salvo de la breve, limitada, geográfica y temporalmente, experiencia estatutaria republicana, los cuerpos polítiços vasco-navarros, eran esencialmente, las provincias exentas y el Viejo Reyno que devino en provincia. Herrero de Miñón propone la fórmula de la novación subjetiva de los derechos históricos vascos, "consistente en introducir junto a Vizcaya, Alava y Guipúzcoa un nuevo titular de derechos históricos, Euskadi", erigiéndose en nuevo corpus politicum foral.

Los Cuerpos Políticos provinciales, que ven paulatinamente aumentadas sus competencias por el Estado, como medio de debilitar la mancomunidad foral, ven actualizados sus derechos históricos por mor de la Adicional Primera de la Constitución y la Adicional del Estatuto de Guernica, de suerte que Vasconia occidental (Euskadi), se "erige en nuevo territorio foral", titular de derechos históricos propios, que se reflejan, competencialmente en el denominado derecho legendario. ${ }^{121}$ Esta transfusio atque translatio en sus primeras interpretaciones, deviene en novación subjetiva que no extingue las titularidades anteriores, sino que se crea una nueva situación de cotitularidad de tales derechos, pero que funcionalmente se atribuyen según las propias normas de distribución de competencias. ${ }^{122}$

Pero a juicio no sólo es un problema de competencias, sino que los derechos históricos son constitutivos del sujeto político transcendental, es el que hace posible «la concurrencia democrática inherente a la autoderminación". ${ }^{123}$

Ambos sujetos, el de la soberanía nacional (pueblo español) y el de la soberanía foral, (pueblo vasco) han sido identificados, en la norma constitucional (art. $1 .^{\circ}$ y 2. ${ }^{\circ} \mathrm{CE} 1978$ y Adicional Primera de la Constitución), y en el caso de Vasconia occidental, dentro del bloque de la constitucionalidad, en el artículo $1 .^{\circ}$ y en la Adicional Primera del Estatuto Vasco. ${ }^{124} \mathrm{Y}$ es la Comunidad Autónoma vasca, en la que se estatuye el Pueblo Vasco, en cuanto "demos", el ámbito político de decisión, en un proceso de autodeterminación. ${ }^{125}$

121. Herrero de MiÑón, Derechos, ob. cit., p. 143.

122. HerRero de MrÑón, "La titularidad de los derechos históricos vascos" en GómEz-FERRER MORANT, Libro Homenaje al Profesor José Luis Villar Palasi, Ed.Civitas. Madrid, 1989, pp. 606 y 607. Y en Derechos bistóricos, ob. cit., p. 142. Lo reitera en su posterior trabajo, Estructura y función de los Derechos bistóri$\cos$, ob. cit., p. 330, "a mi juicio, el antiguo Reino de Navarra es titular de derechos históricos y lo son Euskadi y sus tres territorios históricos, y así lo ha reconocido expresamente el Tribunal Constitucional".

123. Derechos, ob. cit., p. 270.

124. Lo reconoce Juan José SOlOZÁBAL, Autodeterminación y constitución, Cuadernos de Alzate núm. 21, pp. 129-130. La cuestión del "demos" es relevante. Señalaba Peter A. Kraus, "Problemas de democratización en los Estados plurinacionales", RIFP, núm. 8., p. 60 "La validez del principio de soberanía popular depende en gran medida de que se haya creado certidumbre previa y, en cierto grado predemocrática en cuanto a la identidad del pueblo como sujeto político colectivo tal como pone de manifiesto la perspicaz observación de Ivor Jennings (1956, p.56): [ ...] the people cannot decide until somebody decides who are the people. La aplicabilidad de un procedimiento democrático tan elemental como es la regla de la mayoría presupone la existencia de una comunidad política reconocida por los ciudadanos como el marco general y legítimo que les permite articular sus pertinencias individuales y colectivas".

125. Juan José Solóź́BAL, ob. cit. passim, y otros constitucionalistas, ponen en tela de juicio cual sea el sujeto titular del derecho de autoderminación y el consiguiente ámbito de decisión. Sin embargo la construcción normativa de HERRERO DE MiNón, es en este punto, coherente. El juego de la Adicional Constitucional y de la Adicional Estatutaria así lo determinan. El argumento de SolozáBAL me retrotrae a los tiempos universitarios, en aquellas asambleas que se paralizaban al grito eterno y periódico, del 
El pacto, el compromiso es a juicio del autor, el segundo concepto central de la teoría de los derechos históricos. ${ }^{126} \mathrm{Si}$ la naturaleza paccionada del régimen navarro ha sido reconocida -sostiene Herrero de Miñón- otro tanto ocurre con el Estatuto de Guernica, "puesto que los derechos históricos en él instrumentados (arts. 3, 16, 17, 24, 37. 41 EAPV), también lo son sobre la base de la Adicional Primera, y en consecuencia no menos originarios". ${ }^{127}$

Dado el contenido enormente simbólico de la función y de la capacidad integradora en el Estado, se pregunta Herrero de Miñón, si el texto constitucional ofrece estos cauces de integración que excedan del mero formalismo jurídico, para un nuevo Ausgleich constitucional o un nuevo Bake eta Fueroak de la proclama de Muñagorri, que desembocó en el Convenio y en el Abrazo de Vergara. ${ }^{128}$

Sigue existiendo en este tema en la visión normativa y positivista de la Constitución Española de 1978, como recordara Ferrán Requejo, citando al Manuel Azaña de su "Defensa de la Autonomía de Cataluña", algo mal resuelto de carácter substantivo, y no solo procedimental en el actual sistema político español. ${ }^{129}$

Ese mismo Don Manuel Azaña, recuperado hogaño por los herederos del escarnio de antaño, es quien firma y refrenda en el Estado integral republicano, el Decreto de atribución a las corporaciones forales, de las facultades para la promoción y aprobación del Estatuto Vasco. Refrenda Don Manuel Azaña cómo el Gobierno de la República "ha resuelto investir a las Diputaciones de Alava, Vizcaya, Guipúzcoa y Navarra de las facultades necesarias para el encauzamiento de esas aspiraciones, ajustándose a las normas que en relación con las autonomías regionales se han establecido en la Constitución próxima a aprobarse. El gobierno no debe prejuzgar si esa autonomía ha de legalizarse en un estatuto uniforme para las tres provincias Vascongadas y Navarra, o si por el contrario, se articulará en un Estatuto por cada provincia, respondiendo así al régimen tradicional que, con peculiaridades distintas, tuvo

"Votamos primero si se vota". No deja de ser paradójico que los críticos de las tesis de HERRERo en este punto, se centren en el sujeto político titular. Esgrimen, por ejemplo, si le asiste a Álava un derecho de secesión de la CAV en el caso de que siguieran aventuras soberanistas. La propuesta incurre en una contradicción interna, peca de historicista. ¿Por qué Alava? ¿y el valle de Ayala y Aramayona de mayoría nacionalista podrían segregarse, previamente de Alava? ¿Y el resto de las cuadrillas alavesas, salvo la Ciudad de Vitoria, de mayoría nacionalista? Las tesis de HERrERo DE MiNón, han hallado acogida en el grupo pacifista ELKARRI, de donde ha partido una propuesta de pacificación sobre base de la articulación e integración vía pacto que permite la Adicional Primera de la Constitución.

126. HERRERO, Derechos, ob. cit., p. 324. Las propuestas del "arreglo foral" fueron formuladas oportunamente por ilustres administrativistas, bien que con otro alcance, aun cuando guiadas de la misma finalidad integradora. La anticipó T.R. FERNÁNDEZ RODRíguez en su artículo "Los Conciertos Económicos de las provincias vascongadas: aspectos jurídicoadministrativos", en la $R E D A, \mathrm{n} .^{\circ}$ 7, oct/dic. 1975., p. 527, y la recupera en su excelente libro Los derechos históricos de los territorios forales. Bases constitucionales y estatutarias de la Administración foral vasca. Hay una doble edición, Madrid, Civitas, 1985 y Centro de Estudios Constitucionales.

127. HERRERO DE MiNón, Autodeterminación, ob. cit., pp. 220 y 221.

128. Sin ánimo de ser exhaustivos, Joseba AGIRREAZKUENAGA, Gerraren bukaeran bakerik ez, abagune berria baizik, Bakegintza eta Herrigintza gerra karlistetan. Jakin, 113.

129. Veáse Ferrán REQUEJO, "La acomodación federal de la plurinacionalidad. Democracia liberal y federalismo plural en España”, en Enric Fossas y Ferrán REQuEjo (Eds.) Asimetria federal y Estado plurinacional. El debate sobre la acomodación de la diversidad en Canadá, Bélgica y España, Editorial Trotta, Madrid, 1999. 
por Código, los fueros de Alava, Vizcaya, Guipúzcoa y Navarra, cuya diversidad legislativa nunca debilitó los vínculos fraternales que en todo tiempo unieron a las cuatro provincias, y por ello el Gobierno, respetuoso con la voluntad de aquel país, deja a su albedrío esa resolución invitándole a optar por un Estatuto uniforme o por Estatutos diversos". ${ }^{130}$

Lenguaje de derechos históricos en el pensamiento jurídico liberal español que ha sido criticado con la misma "ceguera histórica" que denunciara Arenillas, al criticar la actitud antaño -y hogaño- del Burgsozialismus sobre la cuestión nacional vasca y el Proyecto de Estatuto de Autonomía de Estella (Lizarra) de 1931. ${ }^{131}$

Cierto es que la recuperación del Azaña integrador del estado de los hechos nacionales, el Azaña del discurso de la defensa del Estatuto de Autonomía de Cataluña, es a juicio de la doxa nacional, "la culminación de este sentido oportunista en el modo de ver el problema de la nación española se produce con la defensa cuando menos en dos ocasiones, del derecho de sucesión para Cataluñan (sic). ${ }^{132}$

La paradoja estalla. El constitucionalismo liberal contemporáneo descansa en esa traída y llevada nación de ciudadanos, cuyos rasgos sustanciales son la protección de los derechos individuales fundamentales e indisponibles por el legislador y por el poder constituido, que no estén al albur de la democrácia de la pena de muerte (Zagrebelsky). Sin embargo no resuelve el problema del consentimiento de sus propios ciudadanos que prefieren elegir otra nación de ciudadanos distintos, por razones diversas, y que responden a una elección racional. Si el Estado democrático, como recuerda Herrero de Miñón, es un proceso de integración voluntaria, nada impediria, "si así lo decide mayoritariamente en su propio -ámbito de decisión Euskalerría- y con las mayorías cualificadas que la transcendencia de tal decisión requiera, puede optar democráticamente en pro de su separación respecto de Estado y pactar a continuación con el Estado dicha separación". Como se preguntara Pi i Margall, ¿lo consentirá España? A la vista de los argumentos esgrimidos, el consentimiento desde la nación histórica se ha negado.

Sin embargo desde una teoría garantista de los derechos fundamentales, solamente son indisponibles aquellos, mientras que los "corpora politica", son maleables, dúctiles, intercambiables. En expresión de Zagrebelsky, al definir qué sea la

130. Exposición de Motivos del Decreto de 8 de diciembre de 1931, suscrito por CASARES QuIROGA, como Ministro de Gobernación y refrendado por Manuel Azaña (Gaceta de Madrid, 9 de diciembre de 1931).

131. Son enormente sugerentes las críticas de ARENILLAS, ob. cit., a la actitud del PSOE ante el Proyecto de Estatuto Vasco de Estella de 1931, que califica, como "ceguera histórica de las fuerzas gubernamentales" respecto de los problemas de la cuestión nacional vasca. Ciertamente, hogaño ARENILLA no sería políticamente correcto.

132. Andrés DE BLAS GUERRERO, Tradición republicana y nacionalismo español, Editorial Tecnos, Madrid, 1991, p. 130. No es extraño, las tesis del autor son deudas de cierto liberalismo español -sin liberales- escasamente republicano en el sentido que la revolución francesa dio al concepto. Recientemente Jon JUARISTI, hogaño alto cargo en el gobierno reinante, se declaraba en un períodico de gran tradición liberal y democrátića, deudo del nacionalismo republicano español. Leido el artículo de la edición de El País del 22 de septiembre del 2000, intitulado Contra el nacionalismo vasco, se corrobora su opción por dicha tradición. Únicamente que deberá desprenderse del adjetivo republicano. Melancolía o contradictio in terminis. 
ductilidad constitucional, «la coexistencia de valores y principios, sobre la que hoy debe basarse necesariamente una constitución para no renunciar a sus contenidos de unidad e integración y al mismo tiempo no hacerse incompatible con su base material pluralista, exige que cada uno de tales valores y principios se asuma con carácter no absoluto, compatible con aquellos otros con los que debe convivir."

El constitucionalismo dúctil y útil, que propone Herrero de Miñón, a la postre, y del que se reconoce deudo, "solamente asume carácter absoluto el metavalor que se expresa en el doble imperativo del pluralismo de los valores (en lo tocante al aspecto sustancial) y la lealtad en su enfrentamiento (en lo referente al aspecto procedimental).

El núcleo duro constitucional es, a la postre el Título I de la Constitución Española, el marco de la Constitución al que reenvía la Adicional Primera, mientras que el resto, incluida la propia soberanía "colectiva" del pueblo español, son elementos maleables, modificables, mutables, del orden constitucional. Tales son, recalca el profesor italiano, las exigencias constitucionales de toda sociedad pluralista que quiera ser y preservarse como tal. ${ }^{133}$

Las razones últimas de la soberanía nacional, por tanto, solamente se justifican desde la intransigencia e inmodificabilidad de los derechos individuales. ${ }^{134}$

Lo demás es fruto de la "coexistencia y el compromiso". Si en la integración constitucional hay elementos simbólicos, gestuales, parece apropiado, en su fuero, que la Disposición Adicional Primera, sirva, útilmente, para aparejar, sin fagocitar, a Vasconia en el Leviathan español. ${ }^{135}$ De ahí que las normas constitucionales, amen de ser normas jurídicas, sirvan, funcionalmente para la construcción de una España Grande.

De suerte que la autodeterminación propuesta, "puede ser, también, la base de la integración voluntaria y el pacto su mejor expresión", y para el "españolismo creer de verdad en las capacidades integradoras de una España Grande que no se basa en la coacción, sino en la voluntad de vivir juntos, porque hay razones para ello; cosas que recordar y olvidar juntos y cosas que hacer en común". ${ }^{136}$

133. Gustavo ZaGReBelsKy, El derecho düctil, ob. cit., pp. 14-15.

134. Dicho en primera persona. Siendo ciudadano alavés, me resulta irrelevante, prima facie, desde una concepción liberal del derecho, que mi comunidad imaginada sea la vasca o la española, siempre y cuando queden garantizados mis derechos como sujeto autónomo y responsable de sus actos. En segundo término me resulta más relevante si esa comunidad imaginada, defiende mejor mi ipsiedad, no mi quatenus. Y respeta el derecho ajeno. En tercer término, me resulta más relevante si esa comunidad se articula como una nación de ciudadanos -república- o mantiene vestigios antiliberales, como la monarquía. En cuarto término, me resulta más relevante, desde la teoría de la elección racional, si se organiza desde principios democráticos, además desde fundamentos liberales. En quinto término, me resulta más relevante si en su organización económica se adoptan modelos civilizados, es decir, socialdemócratas. De ahí que resulte alentador, por fín, el artículo de Portillo Valdés, "La vagancia del abertzalismo", revista HIKA número 11, Junio del 2000, al criticar la ausencia de todo proyecto constitucional en las propuestas de la llamada izquierda patriótica.

135. Derechos, ob. cit., pp. 326 y ss. Autodeterminación, ob. cit., pp. 221-223.

136. Autodeterminación, ob. cit., p. 223. Para el abertzalismo aceptar el principio democrático y en tal sentido apuntan las más concretas declaraciones de Lizarra. Tristemente, a la vista de la reanudación de los crímenes de la falange vasca, parece que el "abertzalismo" no ha sido fiel ni pactista a los acuerdos llamados de Estella-Lizarra. Ni al Método, ni al Proceso (Fase preliminar, fase resolutoria, carácter de la negociación, claves de resolución, escenario resultante). Como expusimos 
Para ello, concluye Herrero de Miñón, "un concepto de Constitución, válido para España, ha de cubrir los aspectos formal -constitucionalismo escrito- material -telos de la integración mediante la ordenación fundamental del poder y de la libertad-y normativo", sin que sea un "orden cerrado", sino útil para la finalidad de integrar en la comunidad imaginada, la España Grande, a esa Cofradía de Mareantes vascos que prefieren, como en las antiguas baladas, barloventeas en sus traineras balleneras en el Golfo de Vizcaya y allende los mares constitucionales, sin temor a que el $A c a b$ del nacionalismo español, los arponee. ${ }^{137}$

Escribía Peter Häberle, que "la sociedad abierta de intérpretes y políticos constitucionales" que caracteriza a todo Estado constitucional de cuño occidental -con las limitaciones españolas vistas- se configura fundamental e indeludiblemente a partir de "cristalizaciones culturales" propias. La exégesis constitucional puede lograr mejores cotas de comprensión "entre los textos jurídicos y sus respectivos contextos", de suerte que "todo status constitucional o todo cambio del mismo siempre se revitaliza más intensamente con cristalizaciones culturales propias". ${ }^{138}$

La exégesis de la constitucionalización de los derechos históricos propuesta por Herrero de Miñón, revitaliza ciertamente la función útil e integradora de la Constitución Española de 1978. A nuestras cristalizaciones culturales acudo. No concluiré con el último estudio sobre el multiculturalismo o comunitarismo norteamericano. Mis lecturas son más capolitas. Escribió Alfonso Rodríguez Castelao, Sempre en Gali$z a$, "Maxinemos que na primeira sesion de Cortes constituíntes do ano 1931 se votase unha declaración semellante á que fixeran as Cortes constituíntes do ano 1873. Maxinemos que a nova declaración estivese redactada nos termos que propoñía Rovira i Virgili para despois da guerra, La forma de convivencia de las cuatro naciones bispanas -Castilla, Cataluña, Galicia y Euzcadi- es la República Federal Española. ¿Estaría hoxe Hespaña ensumida no despotismo tradicionalista? ${ }^{139}$

al principio, no pertenecen al fuero del pensamiento nacionalista, su reino es otro. Puede consultarse el texto de los Acuerdos citados en Txiki Benegas, Una propuesta de paz. Espasa Calpe, Madrid. 2000.

137. Lo resume HERRERo dE MiNón, Qué son y para que sirven, p. 322 en los siguientes términos: "primera, la Constitución incluye entre sus principios generales de organización el reconocimiento, de cuerpos políticos diferentes del Estado, titulares de derechos originarios expresivos de su personalidad. Segunda, la configuración jurídica de dichas personalidades políticas las aboca al pacto, de este modo, la relación ha de ser paccionada y no es susceptible de interpretación unilateral y unilateral derogación. Tercera, los derechos históricos suponen signos que configuran la identidad de su titular, que pueden actualizarse pero no derogarlos. Cuarta, los derechos históricos sólo pueden ejercerse y actualizarse democráticamente, decantando la voluntad mayoritaria del pueblo que es su titular. Quinta, por marco de la Constitución han de entenderse los "grandes vínculos institucionales" y la "Comunidades de valores", que en modo alguno "empece un proceso de construcción nacional democráticamente decidido y conducido en virtud de los Derechos Históricos". Estos derechos históricos pueden ser "un encuentro suprapartidista para la paz", y el establecimiento de un régimen singular y la decisión democrática de su futuro. Desde el punto de vista del derecho de autodeterminación, el proceso democrático - autodeterminación interna- permite plantear la autodeterminación externa. Como corolario escribe el autor, si aquélla puede conducir a la independencia, "también puede ser, expresa y áun más, tácitamente, el instrumento de la integración voluntaria del Pueblo Vasco con el Estado. A los españolistas nos corresponde, históricamente, la tarea de plantear en su día la autodeterminación y obener de ella la integración".

138. Peter HäBERLE, Teoría de la Constitución como ciencia de la cultura, ob. cit., pp. 159-160.

139. Alfonso Rodríguez Castelao, Sempre en Galiza, ob. cit., pp. 185-186. 
De las obras citadas de Herrero de Miñón, me resta decir, que pretenden ser propuestas para una forma de convivencia de esta vieja nación de naciones, de las Españas, desde sus creencias monárquicas, que no son ni las de Castelao ni las mías, y de sus convicciones democráticas, que compartimos desde la educada discrepancia.

La lectura de los trabajos de Herrero de Miñón ha sacudido el panorama constitucional español. ${ }^{140}$ Decía Alexis de Tocqueville, que las "naciones son como los hombres: gustán más del ruido que se hace por ellas, que de los servicios reales que se les presta", ${ }^{111}$ Los libros de Herrero de Miñón, están entre los segundos.

Dada la actual mar constitucional, Alfonso R. Castelao hubiera dedicado un retrato en su serie Cousas. Hubiere puesto nombre, con sorna galaica, al «actual despotismo", que se ha instalado en el pensamiento jurídicamente correcto español. Cousas de vellos.

El día de San Formerio, septiembre de 2000.

140. Mis críticas a las tesis de Herrero de MiÑón en La Disposición Adicional Primera, ob. cit., passim.

141. Recuerdos de la Revolución de 1848, Editorial Trotta, Madrid, 1994, p. 254. 